\title{
Relative sea-level change, climate, and sequence boundaries: insights from the Kimmeridgian to Berriasian platform carbonates of Mount Salève (E France)
}

\author{
Telm Bover-Arnal* ${ }^{*}$ André Strasser
}

Département de Géosciences, Université de Fribourg, Chemin du Musée 6, 1700 Fribourg, Switzerland

${ }^{*}$ Corresponding author.

e-mail address: telm.boverarnal@unifr.ch (T. Bover-Arnal) (1)

(1)

Abstract The present study analyzes the stratal architecture of the Late Jurassic (Kimmeridgian) to Early Cretaceous (Berriasian) sedimentary succession of Mount Salève (E France), and four Berriasian stratigraphic intervals containing four sequence-boundary zones reflecting lowering trends of the relative sea-level evolution. Massive Kimmeridgian limestones characterized by the presence of colonial corals appear to be stacked in an aggrading pattern. These non-bedded thick deposits, which are interpreted to have formed in balance between relative sea-level rise and carbonate accumulation, suggest a keep-up transgressive system. Above, well-bedded Tithonian to Berriasian peritidal carbonates reflect a general loss of accommodation. These strata are interpreted as a highstand normal-regressive unit. During the early phase of this major normal regression, the vertical repetition of upper intertidal/lower supratidal lithofacies indicates an aggrading depositional system. This is in agreement with an early stage of a highstand phase of relative sea level. The Berriasian sequence-boundary zones investigated (up to $4 \mathrm{~m}$ thick) developed under different climatic conditions and correspond to higher-frequency, forced- and normal-regressive stages of relative sea-level changes. According to the classical sequence-stratigraphic principles, these sequence-boundary zones comprise more than one candidate surface for a sequence boundary. Three sequence-boundary zones studied in Early Berriasian rocks lack coarse siliciclastic grains, contain a calcrete crust, as well as marly levels with higher abundances of illite with respect to kaolinite, and exhibit fossilized algal-microbial laminites with desiccation polygons. These sedimentary features are consistent with more arid conditions. A sequence-boundary zone interpreted for the Late Berriasian corresponds to a coal horizon. The strata above and below this 
coal contain abundant quartz and marly intervals with a higher kaolinite content when compared to the illite content. Accordingly, this Late Berriasian sequence-boundary zone was formed under a more humid climate. The major transgressive-regressive cycle of relative sea-level identified, and the climate change from more arid to more humid conditions recognized during the Late Berriasian, have been reported also from other European basins. Therefore, the Kimmeridgian to Berriasian carbonate succession of Mount Salève reflects major oceanographic and climatic changes affecting the northern margin of the Alpine Tethys ocean and thus constitutes a reliable comparative example for the analysis of other coeval sedimentary records. In addition, the stratigraphic intervals including sequence-boundary zones characterized in this study constitute potential outcrop analogues for sequence-boundary reflectors mapped on seismic profiles of subsurface peritidal carbonate successions. The detailed sedimentological analyses provided here highlight that on occasions the classical principles of sequence stratigraphy developed on seismic data are difficult to apply in outcrop. A sequence-boundary reflector when seen in outcrop may present successive subaerial exposure surfaces, which formed due to high-frequency sea-level changes that were superimposed on the longer-term trend of relative sea-level fall.

Keywords Berriasian ' sequence stratigraphy ' carbonate platform ' sea-level change · palaeoclimate $\cdot$ France

\section{Introduction}

The vast subtropical to tropical Mesozoic carbonate platforms flourishing throughout the margins of the Tethyan and proto-Atlantic realms were reliable recorders of low- and high-frequency changes in relative sea level (e.g., Pasquier and Strasser 1997; Bádenas et al. 2004; Colombié and Rameil 2007). On the flat-lying platform tops (e.g., Borgomano 2000; Booler and Tucker 2002; BoverArnal et al. 2009) or on gently sloping proximal ramps (e.g., Van Buchem et al. 2002; Aurell and 
Bádenas 2004; Bover-Arnal et al. 2010), even low-amplitude, metric shifts of relative sea level were recorded and are evidenced by repeated subaerial exposure or maximum regressive surfaces followed by transgressive intervals.

Regional to global relative sea-level fluctuations are mainly controlled by glacial and thermal eustasy, thermal and tectonic subsidence, uplift processes, and sediment supply to the basins. The complex interplay between these mechanisms normally results in a hierarchical stacking of the strata that reflects different orders of depositional cyclicity (e.g., Strasser et al. 2006; Spence and Tucker 2007; Catuneanu et al. 2009). The cyclic variations of controlling parameters are highlighted by the repetition of particular lithofacies successions at distinct scales of space and time. The analysis of the different orders of cyclicity in the rock record by means of sequence- and cyclostratigraphy is of importance to interpret the stratigraphic packaging within a basin, to discriminate between autocyclic and allocyclic processes that were responsible for creating the observed sedimentary sequences, and to quantify rates and amplitudes of the controlling processes.

The Berriasian (Early Cretaceous) exposures on the northwestern, almost vertical face of Mount Salève (E France) are a well-studied example of a carbonate sedimentary succession that was controlled by different orders of relative sea-level variations (Strasser 1988; Strasser 1994; Strasser and Hillgärtner 1998; Hillgärtner 1999; Strasser et al. 1999, 2000, 2004; Hillgärtner and Strasser 2003). According to Strasser and Hillgärtner (1998), three different orders of relative sealevel change, which were at least partly governed by orbital forcing, can be interpreted from these platform carbonates. The higher-frequency sea-level fluctuations identified were in tune with the 100-kyr and 400-kyr eccentricity cycles, while the lower-order sea-level changes are correlatable with the Berriasian sequences reported for the European basins by Hardenbol et al. (1998). Accordingly, the Berriasian section of Mount Salève contains 8 sequence boundaries that mark significant long-term falls of relative sea level (Strasser and Hillgärtner 1998). In addition, Strasser (1988) linked smaller-scale, elementary sequences interpreted from the same sedimentary succession to the 20-kyr precession cycle. 

record into genetic units. The sedimentary expression of a sequence boundary related to relative sea-level fall can be very variable depending on the nature and topography of the underlying strata, the time involved in its formation, the climate, the depositional space available, the biotic activity, the physical and chemical oceanographic conditions, the diagenetic processes, the type of sediment supply, and the rates of sedimentation. Four different types of sequence boundary can be formed during regressive stages of relative sea level: the subaerial unconformity, the correlative conformity, the regressive surface of marine erosion, and the maximum regressive surface (Catuneanu et al. 2009). If these surfaces are reworked during the subsequent transgression, the sequence boundary is replaced by a transgressive ravinement surface.

Sequence boundaries Be1, Be2, Be4, and Be8 of Mount Salève (Strasser and Hillgärtner 1998) and the strata below and above these diagnostic surfaces developed under distinct environmental conditions during the Berriasian age. One of the aims of the present paper is to analyze these stratigraphic intervals to provide case studies illustrating distinct sedimentary expressions of a sequence boundary, i.e. different reactions of the depositional environment to lowering sea-level under varying, additional, controlling factors. The stratigraphic intervals examined were chosen because of their excellent exposure and because they each provide unambiguous palaeoclimatic information. The second goal of the paper is to place these Berriasian strata within a large-scale sequence-stratigraphic context comprising the whole of the Kimmeridgian to Berriasian succession that builds up the cliffs of Mount Salève.

Since the earliest days of Geology, Mount Salève has received considerable attention concerning palaeontology, stratigraphy, sedimentology, and structural geology (e.g., de Saussure 1779-1796; Joukowsky and Favre 1913; Carozzi 1955; Lombard 1967; Deville 1991; Gorin et al. 1993; Signer and Gorin 1995). However, none of the published studies have tackled the aforementioned objectives. 
112 Located in the Haute Savoie (E France), to the south of Geneva (Switzerland), Mount Salève rises 113 from the surrounding plains as an elongate structural dome roughly $17 \mathrm{~km}$ long and $3 \mathrm{~km}$ wide (Fig.

114 1). This structure represents the Mesozoic head of a thrust-sheet that overrides the Late Oligocene 115 Early Miocene Molasse basin (Gorin et al. 1993). Steep cliffs at the northwestern side expose a 116 Kimmeridgian to Late Berriasian sedimentary succession composed of marine platform carbonates, 117 which occasionally alternate with freshwater limestones (Strasser 1988; Deville 1991). The 118 Berriasian strata analyzed in this study are found in these cliff exposures (Fig. 1), along an almost 119 vertical section that commences at the intersection between the Chavardon and Etiollets trails, 120 follows uphill along the Etournelles trail, and ends above the Corraterie trail (see Strasser and 121 Hillgärtner 1998).

The Late Jurassic stratigraphy of Mount Salève lacks precise dating and formal stratigraphic units (Deville 1991). Coral-bearing limestones, which belong to the "Calcaires à tertres récifaux des Etiollets" Member of the informal formation of the "Calcaires coralliens des Etiollets" (Fig. 2; Deville 1990), are of probable Kimmeridgian (-Tithonian?) age and build up the lower part of the succession. Above, limestones containing oncoids are interpreted to be equivalent to the Chailley Formation of Enay (1965) (Fig. 2) and, thus, of Tithonian age (Bernier 1984). The Berriasian succession covers a time interval of 5.3 My (according to Gradstein et al. 2004), is $154 \mathrm{~m}$ thick (Strasser and Hillgärtner 1998), and can be divided into 5 lithostratigraphic units with the rank of 130 formations: Tidalites-de-Vouglans, Goldberg, Pierre-Châtel, Vions, and Chambotte (Fig. 2; Häfeli 131 1966; Steinhauser and Lombard 1969; Bernier 1984). The age of the deposits has been calibrated by 132 ammonite and calpionellid biostratigraphy (Le Hégarat and Remane 1968). This biostratigraphic 133 framework is strengthened by high-resolution cyclostratigraphic analyses and the identification of 8 134 sequence boundaries with regional significance (Strasser and Hillgärtner 1998), which enables 135 correlations with hemipelagic basins where more precise biostratigraphic dating is available 


\section{Data collection and methods}

The strata below and above the sequence boundaries $\mathrm{Be} 1, \mathrm{Be} 2, \mathrm{Be} 4$ and $\mathrm{Be} 8$ of Strasser and Hillgärtner (1998) were logged and sampled for sedimentological and petrographical analyses. The beds giving rise to these sedimentary successions were labeled with letters and numbers to facilitate their detailed description. In this regard, A1-H1, A2-O2, A4-G4 and A8-V8 correspond to the strata encompassing the sequence boundaries $\mathrm{Be} 1, \mathrm{Be} 2, \mathrm{Be} 4$ and $\mathrm{Be} 8$, respectively. Microfacies were studied from 99 thin sections. Panoramic photomosaics of Mount Salève taken from the environs of the villages of Troinex (Switzerland), Veyrier (Switzerland), and Collonges-sous-Salève (France) were used for mapping, line-drawing, and the large-scale sequence-stratigraphic analysis. The sequence-stratigraphic interpretation is based on the lithofacies evolution and stacking patterns mapped during field work and observed with binoculars from a distance. The terminology used for the rock textures and the sequence-stratigraphic interpretation follows Dunham (1962) and

153 Catuneanu et al. (2009), respectively.

\section{Large-scale sequence-stratigraphic context}

The overall stratal architecture of Mount Salève can be divided into two large-scale genetic types of 158 deposit, which reflect major trends of the relative sea-level evolution. The first unit comprises 159 Kimmeridgian non-bedded coral-bearing limestones, which appear to be arranged in an aggrading 160 pattern (Figs. 3 and 4a). This aggrading succession, which is up to several tens of metres thick, is 161 interpreted as a large-scale transgressive deposit whereby increasing accommodation was 
162

163

164

continuously filled by sediment (Colombié and Strasser 2005). Above, Tithonian to Berriasian wellbedded peritidal carbonates (around 200 m thick; Strasser and Hillgärtner 1998; Hillgärtner 1999) reflect a decreasing rate of accommodation gain and are interpreted as highstand normal-regressive deposits (Figs. 3 and 4b). According to the laterally continuous and horizontal geometries, and due to the absence of step-like structures (Fig. 3), the Tithonian to Berriasian depositional profile of Mount Salève corresponded to a flat-topped platform or a low-angle homoclinal ramp. On account of the two-dimensional aspect of the outcrop, it is not possible to determine the directions of retrogradation and progradation.

\section{Anatomy of sequence boundaries}

\section{Sequence boundary Be1}

The stratigraphic interval analyzed surrounding sequence boundary (SB) Be1 commences in the uppermost Chailley Formation (A1 in Figs. 5 and 6). The top of this formation is characterized by metre-thick moderately-sorted grainstones (Fig. 7a) containing peloids, micritic oncoids, other coated grains, Andersenolina cf. alpina, Mohlerina basiliensis, other unidentified foraminifera, and skeletal fragments of green algae, echinoids, bivalves, and gastropods. No hydrodynamic structures were recognized. Keystone vugs pointing to upper intertidal to lower supratidal conditions (Dunham 1970) appear in the uppermost part of the bed.

The upper limit of the Chailley Formation corresponds to an unconformable surface that defines the limit with the Tidalites-de-Vouglans Formation (Figs. 2, 5 and 6). This surface is overlain by decimetre-thick channelized beds, which exhibit erosional features and partly pinch out laterally (B1 in Figs. 5 and 6). The channelized deposits display packstone to grainstone textures 
and are distinguished by the presence of black granules and pebbles, peloids, micritic oncoids, other coated grains, Andersenolina sp., other unidentified foraminifera, and fragments of molluscs, echinoids, serpulids, corals, and dasycladaceans. These deposits are thought to have formed in the shallow subtidal realm, influenced by currents that eroded pre-existing carbonate sands and shifted sediment lobes.

The channelized and erosive subtidal strata pass laterally and upwards into decimetre-thick beds, which exhibit a mudstone texture with mm-thin laminations (C1 and E1 in Figs. 5 and 6). Locally, these levels are dolomitized. They are interpreted as algal-microbial mats that formed in low-energy upper intertidal to lower supratidal conditions (e.g., Shinn et al. 1969). Millimetre- to centimetre-thick horizons of sand-sized moulds of skeletal fragments (Fig. 7b) are interpreted as storm deposits on the tidal flat. Black granules and pebbles (Fig. 7c), other lithoclasts, mud pebbles and mud drapes, as well as ripple structures (Fig. 7d) are also common in these deposits, pointing to reworking and tidal influence. Black pebbles and granules are furthermore indicative of nearby subaerial emergence (Strasser and Davaud 1983). Centimetre-thick beds with a wackestone texture are locally found intercalated between the algal-microbial mat layers (D1 in Figs. 5 and 6). These deposits contain black granules and pebbles, miliolids, Andersenolina sp., other unidentified foraminifera, ostracodes, molluscs, dasycladaceans, and charcoalified fragments of conifers (Fig. 7e). They formed in a subtidal, low-energy environment.

Above, a metre-thick dolomitic limestone bed (F1 in Figs. 5 and 6) exhibits a wackestone texture (Fig. 7f) and includes black granules and pebbles, porocharacean remains, ostracodes, charcoalified plant fragments, and unidentified foraminifera. Given the homogeneous high population density of porocharacean gyrogonites and stems, this bed is seen as representing a brackish-water environment (e.g., Climent-Domènech et al. 2009). Decimetre-thick low-energy wackestones dominated by miliolids, reworked porocharacean gyrogonites and fragments of bivalves, gastropods and dasycladaceans then indicate a marine transgression (G1 in Fig. 5). Upwards in the succession, the wackestone beds evolve into metre-thick massive dolomitic 
214 limestones (H1 in Fig. 5). The base of these deposits comprises mudstones and brecciated fabrics 215 with miliolids, other unidentified foraminifera, micritic oncoids, and fragments of green algae. 216 Above, poorly-sorted grainstones with peloids, micritic oncoids, ooids, unidentified foraminifera 217 and fragments of echinoids, dasycladaceans and molluscs dominate.

Sequence boundary Be2

The lower part of the stratigraphic interval that comprises SB Be2 corresponds to decimetre-thick beds (Fig. 4b) with wackestone texture containing peloids, oncoids, and fragments of molluscs and green algae (A2-C2 in Fig. 8). These low-energy subtidal lithofacies evolve upwards in the succession to decimetre-thick mudstones (D2-E2 in Figs. 8 and 9) exhibiting desiccation cracks (Fig. 10a) and represent the low-energy intertidal to supratidal realm (e.g., Hardie 1977). The top of bed E2 with the well-developed desiccation polygons corresponds to the top of the Tidalites-deVouglans Formation.

Above, a marly interval of $5 \mathrm{~cm}$ (F2 in Figs. 8 and 9) is followed by a $45 \mathrm{~cm}$ thick bed of 231 very well-sorted grainstone (G2 in Figs. 8, 9 and 10b), which displays keystone vugs (Fig. 10c) and bi-directional cross-bedding structures. It contains black granules and pebbles, other lithoclasts, micritized ooids, and fragments of bivalves and gastropods. The bed is partially broken into blocks and the fractures that delimit the different blocks are filled with breccia/conglomerate deposits (Fig. 10d) made up of black granules and pebbles and other sand- to cobble-sized lithoclasts. This bed is interpreted as a tidally-influenced ooid sand sheet that developed a beach on its top, as indicated by the keystone vugs. Subsequent rapid cementation turned it into beachrock, which probably was then undercut by waves, fractured and dismantled into blocks (e.g., Strasser et al. 1989). The marly 

Strasser 1987).

The grainstone bed is overlain by a calcrete crust (up to $4 \mathrm{~cm}$ thick), which indicates longlasting subaerial exposure (H2 in Figs. 8, 9 and 10e; e.g., James 1972; Robbin and Stipp 1979). The sedimentary succession continues with a centimetre-thick marly level followed by a decimetre-thick breccia/conglomerate (I2 in Figs. 8, 9 and 10e) with poorly sorted, subangular to subrounded clasts ranging from 1 to $30 \mathrm{~cm}$ in diameter. The clasts display at least three different lithologies: i) a very well sorted grainstone with micritized ooids and fragments of molluscs corresponding to bed G2, ii) a black oolite, and iii) a wackestone to packstone with peloids, oncoids, and fragments of bivalves and gastropods. This breccia/conglomerate is interpreted to have formed in a high-energy inter- to supratidal beach environment, reworking previously cemented sediment of different origins (e.g., El-Sayed 1999; Stephenson and Naylor 2011).

The breccia/conglomerate passes upwards into a wackestone of $35 \mathrm{~cm}$ (J2 in Figs. 8 and 9) with black granules and pebbles, other lithoclasts, peloids, ooids, miliolids, other unidentified foraminifera, and fragments of molluscs and dasycladaceans. Above this wackestone, a centimetrethick marly interval (K2 in Figs. 8 and 9) rich in green illite (Deconinck and Strasser 1987) is followed by a coarsening-upwards mudstone to well sorted, bi-directionally cross-bedded grainstone containing keystone vugs, mud pebbles, peloids, ooids, miliolids, and fragments of echinoids, molluscs and green algae (L2 in Figs. 8, 9 and 10f). The top of this high-energy, tidallyinfluenced deposit is erosive and overlain by a poorly sorted breccia/conglomerate (M2 in Figs. 8, 9 and 10f) with clasts up to $30 \mathrm{~cm}$ in diameter. The clast lithology corresponds to the one of bed L2 below. Above, a metre-thick massive packstone to grainstone bed (N2-O2 in Figs. 8 and 9) containing black granules and pebbles, peloids, ooids, oncoids, miliolids, other unidentified foraminifera, and skeletal fragments of echinoids, bivalves, gastropods and dasycladaceans is attributed to a normal-marine and subtidal environment. 
267 Sequence boundary Be4

269 The interval comprising SB Be4 is located around the limit between the Goldberg and Pierre-Châtel 270 formations (Figs. 2, 11 and 12). Wackestones (A4-B4 in Fig. 11) containing ostracodes, serpulids, 271 and fragments of unidentified molluscs are attributed to a low-energy subtidal environment. They 272 are followed by thinly laminated mudstones with birdseyes (Fig. 13a) and desiccation cracks (C4 273 and D4) representing the low-energy upper intertidal to lower supratidal zone (e.g., Hardie 1977). 274 These are then overlain by a $50 \mathrm{~cm}$-thick bed of breccia/conglomerate with a marly matrix (E4 in 275 Figs. 11 and 12). The lithoclasts, some of them blackened, have diameters of up to $30 \mathrm{~cm}$ and 276 display at least two different lithologies: i) a packstone-grainstone texture with lithoclasts, peloids, 277 miliolids, Andersenolina sp. and fragments of molluscs, and ii) a wackestone texture with 278 lithoclasts, porocharacean remains, peloids, and fragments of molluscs and dasycladaceans. The 279 lithoclasts were not transported from continental to coastal settings by rivers given that their edges 280 are mostly angular, and the lithofacies are identical to the beds found above and below the 281 breccia/conglomerate level. Laterally, in an outcrop $200 \mathrm{~m}$ to the NE, individual beds that sourced 282 the lithoclasts are still recognizable (Strasser 1994). The lithoclasts were neither eroded from a 283 palaeocliff. If so, they would be found within the beds below and above the breccia/conglomerate 284 horizon as well. The breccia/conglomerate thus indicates a high-energy beach setting with 285 production of cobble- to boulder-sized clasts by erosion of pre-existing limestone beds (e.g., El286 Sayed 1999; Stephenson and Naylor 2011).

Above the breccia/conglomerate, a 15 cm-thick wackestone (F4 in Fig. 11, 12 and 13b) with 288 abundant ostracodes and porocharacean gyrogonites and thalli (Fig. 13c) is embedded between two 289 centimetre-thick marly intervals (Fig. 11). This facies formed in a brackish-water environment (e.g., 290 Climent-Domènech et al. 2009). The marls are rich in green illite (Deconinck and Strasser 1987). 291 The marly layers are too thin to be washed and analyzed for fossil contents. However, marls in 
other intervals in the Salève section have furnished porocharaceans and brackish ostracods that have

293 been used for biostratigraphy (Mojon 1988). The overlying sharp surface corresponds to the base of 294 the Pierre-Châtel Formation. Its lower part consists of thick beds of cross-bedded, moderatelysorted grainstone (Fig. 13d), which indicates high-energy subtidal conditions (G4 in Figs. 11, 12 and 13b). The components present in this grainstone are peloids, ooids, other coated grains, Andersenolina sp., other unidentified foraminifera, fragments of coral and bryozoan colonies, echinoids, dasycladaceans, bivalves, and gastropods.

Sequence boundary Be8

The stratigraphic interval comprising SB Be8 begins in the uppermost part of the Vions Formation

(Figs. 2, 14 and 15) with massive limestone beds (A8-B8 in Fig. 14) exhibiting a moderately-sorted grainstone texture (Fig. 16a) and containing ooids, peloids, miliolids, Andersenolina delphinensis, other unidentified foraminifera, and skeletal fragments of echinods, molluscs and algae such as Clypeina parasolkani. They point to high-energy subtidal conditions. Above these grainstones, the carbonate succession becomes siliciclastic influenced and is composed of bedded limestones with quartz sand (Fig. 16b). They have wackestone and packstone textures and contain peloids, scarce

311 ooids, miliolids, other unidentified foraminifera, and fragments of echinoids, oysters, other 312 unidentified bivalves, gastropods, Clypeina aff. estevezi, and other green algae (C8-J8 and L8-M8 313 in Figs. 14 and 15). Bioturbation with Thalassinoides trace fossils is common. The beds display a 314 reddish colour due to iron impregnation (Fig. 16c). A decimetre-thick marly interval is also found 315 intercalated between these levels (K8 in Figs. 14 and 15). The marls are rich in kaolinite 316 (Hillgärtner 1999). 
318 coal horizon (N8 in Figs. 14 and 15; Fig. 16c). Rare root traces penetrate a few centimeters into the 319 underlying sediment. The coal level is seen to represent a tide-influenced swamp (e.g., Shao et al. 320 1998) with brackish to fully marine seawater that formed on top of the bioturbated subtidal facies 321 and that was preserved in anoxic conditions. The surface on top of bed M8 constitutes the limit 322 between the Vions and Chambotte formations (Figs. 14 and 15). Above, a $40 \mathrm{~cm}$-thick bioturbated 323 (Fig. 16d) sandy limestone bed displaying a packstone texture with peloids, miliolids, other 324 unidentified foraminifera, and skeletal fragments of echinoids, molluscs and dasycladaceans 325 indicates the return to low-energy subtidal conditions (O8 in Figs. 14 and 15). Upwards in the succession, the packstone is followed by bedded sandy limestones with a moderately-sorted grainstone texture, including peloids, miliolids, Nautiloculina cf. brönnimanni, 328 other foraminifera, and fragments of echinoids, oysters, other bivalves, gastropods and 329 dasycladaceans (P8-T8 in Figs. 14 and 15). Locally, burrow bioturbation occurs. These grainstones 330 are succeeded by massive sandy limestones exhibiting a packstone texture, which is dominated by 331 peloids, miliolids, other unidentified foraminifera, and fragments of oysters, other unidentified 332 bivalves, gastropods, echinoids and dasycladaceans (U8-V8 in Fig. 14). The facies of beds P8 to V8 333 indicate subtidal, normal-marine conditions. Figures 14 (respect original size), 15 (width of page) and 16 (width of page) near here

Key fossil-markers widely known from Mount Salève such as Favreina salevensis, Clypeina jurassica, Montsalevia salevensis and Hypelasma salevensis (e.g., Joukowsky and Favre 1913; 339 Gourrat et al. 2003) were not identified in the rocks and thin sections analyzed.

\section{Discussion}


345 In two-dimensional tectonized outcrops lacking lateral stratal terminations such as the northwestern 346 face of Mount Salève (Fig. 3), it is always risky to perform sequence-stratigraphic analyses. 347 However, the large-scale architectural and sequence-stratigraphic interpretation of the Late Jurassic 348 (Kimmeridgian) to Early Cretaceous (Berriasian) sedimentary succession examined is consistent 349 with the lithofacies evolution and the stacking patterns observed.

The Kimmeridgian coral-bearing limestones of the lower part of the succession lack clear 351 bedding planes (Figs. 3 and $4 \mathrm{a}$ ). Massive deposits of several tens of metres thick such as these 352 Kimmeridgian rocks imply rising relative sea level and creation of depositional space, which was 353 continuously filled by carbonate sediments. This scenario suggests a keep-up carbonate system, 354 which can be interpretated as a large-scale transgressive genetic type of deposit. On a regional 355 scale, this interpretation is in accordance with the results of Colombie and Strasser (2005) who 356 describe a coeval carbonate system in northwestern Switzerland that kept up with relative sea-level 357 rise.

The Tithonian to Berriasian deposits of the upper part of the succession exhibit well-bedded strata (Figs. 3 and $4 \mathrm{~b}$ ) which, in contrast to the massive Kimmeridgian rocks, are interpreted to 360 reflect generally low accommodation gain. The lithofacies were generated in very shallow subtidal, 361 intertidal and even supratidal environments (Figs. 5-16) and thus indicate shallower settings than 362 the Kimmeridgian coral-bearing limestones. In the context of generally low accommodation, low363 amplitude and high-frequency sea-level fluctuations created significant bedding surfaces, whereas 364 during the major transgression such sea-level changes did not, or only indirectly, influence 365 sedimentation (Strasser et al. 1999). These sedimentological considerations are consistent with a 366 major highstand normal-regressive stage of relative sea-level evolution (Figs. 3 and 4a). There is no 367 discrete surface developed on top of the Kimmeridgian limestones that could qualify as maximum368 flooding surface. Instead, the interval located at the boundary between the massive Kimmeridgian 369 deposits and the well-bedded Tithonian to Berriasian strata is interpreted as a maximum-flooding 
zone (Figs. 3 and 4a). The observed transgressive-regressive trend of relative sea-level change with the turn-around towards the end of the Kimmeridgian has been documented also in other European basins and corresponds to a major transgressive-regressive cycle of Hardenbol et al. (1998) (Fig. 2).

\section{Sequence boundaries in peritidal carbonates}

In platform carbonates, one of the unequivocal sedimentary expressions of relative sea-level fall that are usually chosen as sequence boundaries are karstified horizons (e.g., Van Buchem et al. 2002; Bernaus et al. 2003; Bover-Arnal et al. 2011). In this regard, no evidence of karstification was recognized in the studied sedimentary succession of Mount Salève. Nevertheless, the Berriasian strata examined above and below the sequence boundaries Be1, Be2, Be4 and Be8 of Strasser and Hillgärtner (1998) are formed by shallow subtidal deposits alternating with intertidal and/or supratidal lithofacies (Figs. 5-16), which manifest low accommodation when compared to the lithofacies exhibited by the underlying Kimmeridgian and Tithonian rocks.

When succeeding beds composed of intertidal and/or supratidal lithofacies are present and the different hierarchical levels of the surfaces bounding these strata cannot be established, it is difficult to attribute the sequence boundary to a specific bedding plane. In such cases it is best to indicate a "sequence-boundary zone" (Montañez and Osleger 1993; Strasser et al. 1999), which defines a stratigraphic interval comprising the shallowest facies and/or reflecting reduced depositional space.

\section{Sequence boundary zone Be1}

Strasser and Hillgärtner (1998) placed sequence boundary Be1 at the top of the stratigraphic unit A1 (Fig. 5). This deposit is mainly formed by subtidal lithofacies, but the uppermost part exhibits keystone vugs, which are indicative of high-energy upper intertidal to lower supratidal 
beach settings (Dunham 1970). In addition, the bed is truncated by an erosive surface that is

397 consistent with, but does not prove, subaerial exposure (Fig. 6). Thus, this surface constitutes a 398 suitable option for a sequence boundary. However, above Be1, inter- and supratidal lithofacies (C1, 399 E1 and F1) still occur intercalated between subtidal deposits (B1, D1 and G1). These peritidal 400 lithofacies are characterized by algal-microbial laminites (Fig. 7b) typical of the upper part of a 401 tidal flat (e.g., Shinn et al. 1969) and by homogeneous populations of porocharaceans (Fig. 7f), 402 which commonly developed in brackish-water ponds or marshes (e.g., Climent-Domènech et al. 403 2009). These low-energy inter- to supratidal deposits certainly were accumulated in more proximal 404 settings than the high-energy grainstone (A1; Fig. 7a) with keystone vugs. Moreover, the strata 405 overlying the top of A1 display a thickening-thinning trend in the following $4 \mathrm{~m}$ (B1-G1), 406 suggesting that accommodation increased then decreased after the formation of the erosional 407 surface Be1 (Fig. 5). The overlying stratigraphic unit H1 is $8 \mathrm{~m}$ thick and marks a significant gain 408 of depositional space. It also contains fully marine subtidal facies and thus formed during relative 409 sea-level rise. Therefore, the sequence boundary Be1 would be best represented by a sequence410 boundary zone comprising the uppermost part of stratigraphic unit A1 and units B1 to F1 (Figs. 5 411 and 6). Strasser and Hillgärtner (1998) interpreted the interval covered by units B1 to F1 as having 412 formed by two sea-level cycles in tune with the 100-kyr orbital eccentricity cycle. These higher413 frequency sea-level changes were superimposed onto the lower-frequency trend that was 414 responsible for the sequence-boundary interval with low accommodation. Nevertheless, some 415 accommodation had to be available to record the observed sequences but carbonate accumulation 416 was high enough to maintain the sediment surface in the intertidal or supratidal zone.

418 Sequence boundary zone Be2 mudstone deposits exhibiting desiccation polygons (E2; Figs. 8 and 10a), which are characteristic of 
422 the upper transitional part of the intertidal flat (e.g., Hardie 1977). Given that these layers with 423 mud-cracked surfaces (D2-E2) are stratigraphically above low-energy subtidal wackestones (A2424 C2), they do mark a shallowing-up. This could have been achieved by simple filling in of 425 depositional space but could also have been forced by a slight drop in relative sea level. 426 Accommodation had to be created again to form the ooid shoals represented by unit G2 (Fig. 8), 427 which were cemented as beachrock and covered by calcrete (H2; Fig. 10e) during a subsequent 428 relative sea-level drop. The fact that at least three different lithologies occur within the 429 breccia/conglomerate (I2; Figs. 9 and 10e) implies that these sediments must have accumulated, 430 then lithified, and were reworked during one or several sea-level cycles (one bed may contain 431 several lithologies, or several beds can have the same lithology). Accommodation in this case was 432 not enough to record individual beds but only the products of dismantling and reworking. This 433 scenario is repeated once more to form units L2 and M2 (Figs. 9 and 10f), albeit with less 434 reworking since the clasts in M2 correspond to the underlying facies. Strasser and Hillgärtner 435 (1998) proposed that the interval between units F2 and M2 corresponds to two (100 kyr) sea-level 436 cycles. Hence, a sequence-boundary zone including the stratigraphic units D2-M2 (Figs. 8 and 9) 437 would be more appropriate to describe this interval of generally low accommodation than a single 438 sequence-boundary surface. The stratigraphic units N2 and O2 mark the start of the transgression 439 above the sequence-boundary zone, given that they display an increased thickness and, thus, a gain 440 of accommodation with respect to the succession below (Fig. 8).

Sequence boundary zone Be4

Following the same criteria as for sequence boundary Be2, Strasser and Hillgärtner (1998) positioned sequence boundary Be4 surmounting inter- to supratidal algal-microbial mat deposits 446 with desiccation cracks and birdseyes (C4-D4; Figs. 11 and 13a). Above this surface, however, a 447 breccia/conglomerate (E4; Fig. 13b) indicating a high-energy inter- to supratidal beach zone (e.g., 
El-Sayed 1999; Stephenson and Naylor 2011) and a layer containing monospecific populations of poracharaceans (F4; Fig. 13c) typical of brackish marsh environments (e.g., Climent-Domènech et al. 2009) imply that the marine regression continued throughout the stratigraphic units E4-F4. Consequently, the sequence boundary would be best characterized by a zone including the beds C4F4 (Figs. 11 and 12). The metric thickness of the cross-bedded grainstone G4 indicates that the gain of depositional space linked to the subsequent transgressive pulse occurred above the sequenceboundary zone. The upward passage from inter-/supratidal (F4) to subtidal (G4) lithofacies is in agreement with this reasoning (Fig. 11). According to the interpretation of Strasser and Hillgärtner (1998), $400 \mathrm{kyr}$ are comprised in unit E4. This corresponds to the hiatus between the Goldberg and the Pierre-Châtel formations evidenced by biostratigraphy (Clavel et al. 1986) and indicated in Figure 2.

Sequence boundary zone Be8 clayey coal level (N8; Figs. 14, 15 and 16c), which crops out in the uppermost part of the Berriasian succession. In carbonate platform environments, coal typically accumulates in brackish to fully marine swamps developed on the tidal-flat (e.g., Shao et al. 1998). Given that subtidal deposits, thus deeper lithofacies, characterize the strata above and below this coal-bearing horizon, the base of this inter- to supratidal level constitutes a good candidate for a sequence boundary. Consistently, this surface exhibits scarce root traces (Fig. 14). Nevertheless, the latter surface cannot be followed 469 basinwards and, therefore, it is not possible to discriminate whether or not it was generated during 470 the lowest point of relative sea-level. In siliciclastic coastal systems, coals are commonly 471 interpreted to be formed and preserved during transgression (e.g., Coe et al. 2003). However, the coal horizon observed at Salève is only 2 to 3 centimetres thick and disappears laterally. Such a 
preserved during a high-frequency transgressive pulse superimposed on the long-term sea-level fall. In this respect, the lowest point of long-term relative sea level could also be located within or at the top of the coal layer. Then, the base of the coal accumulation would correspond to a basal surface of forced regression sensu Hunt and Tucker (1992). Given that the sequence-stratigraphic significance and hierarchy of the different surfaces cannot be determined, in this last case study, a zone covering the entire coal-bearing horizon would best represent the sequence boundary (Fig. 14).

The making of sequence boundaries

The sequence-boundary zones discussed here (Figs. 5, 8, 11 and 14) provide stratigraphic windows illustrating the sedimentary response of carbonate platforms to forced regressive and lowstand normal-regressive stages of relative sea-level change. To determine the origin of relative sea-level fluctuations in carbonate sedimentary successions is always a difficult task and not free of controversies. Above all, in outcrops of reduced lateral extension where a perspective of the basinwide stratigraphic evolution is lacking, assumptions are unavoidable. Numerous natural processes could have acted, either in isolation or combined, to generate the long-term lowering stages of relative sea level recognized in the geological record analyzed. These potential mechanisms are summarized in Immenhauser (2005) and mainly include glacio-eustasy, tectono-eustasy, and thermo-eustasy.

According to Strasser and Hillgärtner (1998), the Berriasian sequence boundaries of Mount Salève can be explained as corresponding to Tethyan long-term (third-order) relative sea-level falls (Hardenbol et al. 1998). Recently, Boulila et al. (2011) have concluded that most of the Mesozoic third-order sea-level changes reported worldwide seem to be linked to long-period astronomical cycles.

The long-term regressive phases recognized are overprinted by a higher-frequency evolution of relative sea level. The stratigraphic packaging within the sequence-boundary zones has been 
regarded mainly as the result of orbitally controlled amplitude changes in eustatic sea level, which

501 were to some extent distorted by synsedimentary tectonics (Strasser 1988; Strasser 1994; Strasser 502 and Hillgärtner 1998). In addition, autocyclic processes such as variations in the rates of carbonate 503 production and accumulation or the lateral migration of peritidal facies belts (e.g., Hardie 1977; 504 Pratt and James 1986) certainly have also played a part in the formation of the stratigraphic record. 505 Accordingly, to link the lithofacies evolution observed to determined shifts in the amplitude of 506 relative sea-level change is not free of uncertainties, especially if the degree of completeness of the 507 stratigraphic record is not known. Nevertheless, some aspects concerning the making of the 508 sequence-boundary zones can indeed be considered.

The sequence-boundary zones containing stratigraphic surfaces Be2 and Be4 (Figs. 8 and 11) are characterized by the presence of reworked, previously lithified sediments, which are absent in $\mathrm{Be} 1$ and Be8. These breccia/conglomerate horizons (Figs. 8, 9, 11 and 12) highlight the 512 importance of reworking processes in peritidal zones (e.g., Wright 1984; Strasser and Davaud 513 1986). Commonly such intraclasts are transported to foreshore and backshore environments during 514 storm events, although detached beachrock slabs may slide into the shallow subtidal realm as well. 515 The breccia/conglomerate deposits contain cobble- to boulder-sized clasts exhibiting distinct 516 microfacies. These lithoclasts constitute the only records of completely dismantled depositional 517 sequences, which were not preserved in the section logged but may be still recognizable in nearby exposures (Strasser 1994).

The preservation of these breccia/conglomerate levels, which are indicative of ancient highenergy intertidal settings, is exceptional because high-energy intertidal zones are very limited in 521 extent in comparison to the supratidal, subtidal and low-energy intertidal zones. It is also 522 exceptional to find them preserved in a vertical sedimentary succession. If such a small depositional 523 area persists in several stratigraphic levels in the same geographical position, this indicates that the 524 sedimentary system was relatively stable and did not suffer significant shifts of facies belts 525 (retrogradation or progradation). Therefore, rates of carbonate production and accumulation, higher- 
526 frequency sea-level changes, and subsidence during the time interval comprised between sequence 527 boundary zones $\mathrm{Be} 2$ and $\mathrm{Be} 4$ may have been controlled by similar, recurrent patterns (also 528 sequence-boundary zone $\mathrm{Be} 3$, not documented in the present study, exhibits a breccia/conglomerate 529 level; Strasser and Hillgärtner 1998). Aggradational sedimentary systems are typical of early stages 530 of highstand normal regression (Neal and Abreu 2009; Catuneanu et al. 2009). Hence, these 531 observations would be in accordance with the large-scale sequence-stratigraphic framework 532 proposed herein (Figs. 3 and $4 \mathrm{a}$ ).

The imprint of climate on the sequence-boundary zones interpreted is also noticeable.

534 Sequence-boundary zone Be8 is constituted by a coal level (Figs. 14 and 16C), which is overlain 535 and underlain by strata containing abundant quartz grains (Figs. 14 and 16B). The marls preserved 536 in this stratigraphic interval are rich in kaolinite (Hillgärtner 1999) that is commonly formed in 537 palaeosoils developed under humid conditions (e.g., Curtis 1990). Coal deposits represent the 538 preservation in shallow, oxygen-poor waters of vegetation that flourished in a humid climate (e.g., 539 Parrish et al. 1982). Together, these sedimentary features indicate that this stratigraphic interval was 540 formed under a humid climate (Fig. 2). The sudden appearance of siliciclastics in this Berriasian 541 carbonate succession (Fig. 14) is symptomatic of uplift processes, with additional intensified 542 continental weathering and runoff rates linked to an accelerated hydrological cycle (e.g., Leeder et 543 al. 1998). The iron that gives the reddish stain to the rock was washed into the system together with 544 the siliciclastics.

On the other hand, sequence-boundary zones Be1, Be2 and Be4 (Figs. 5, 8 and 11) lack 546 evidence of siliciclastic input and contain algal-microbial mat deposits (Figs. 7B and 13A), which 547 exhibit desiccation cracks (Fig. 10A) and, in the case of sequence-boundary zone Be1, are partly 548 dolomitized. Algal-microbial mat deposits with mud cracks are common in modern tidal flat 549 environments developed in arid to semiarid areas (e.g., Alsharhan and Kendall 2003). The 550 sequence-boundary zone Be2 includes a calcrete crust (Figs. 8 and 10e). Calcretes are mainly 551 formed in semi-arid to arid environments (Scholle and Ulmer-Scholle 2003). Therefore, these 
sedimentary peculiarities coupled with the absence of terrigenous grains indicates a more arid climate (Fig. 2). In addition, the marly levels preserved in these stratigraphic intervals (Figs. 8 and 11) contain green illite that formed by wetting and drying in the intertidal zone (Deconinck and Strasser 1987). Higher abundances of illite with respect to kaolinite are commonly interpreted to reflect more arid climates (e.g., Ruffell et al. 2002). Pseudomorphs after gypsum and anhydrite have been found only in two levels between sequence-boundary zones $\mathrm{Be} 2$ and $\mathrm{Be} 3$, and the depositional environment there was interpreted as a sabkha (Strasser and Hillgärtner 1998). However, evaporite pseudomorphs are common in the Goldberg Formation in the Swiss Jura (Strasser 1988).

This climate change from more arid conditions (sequence-boundary zones Be1, Be2 and Be3) to a more humid climate (sequence-boundary zone Be8) during the Late Berriasian (Fig. 2) has been recognized also in other coeval geological records from other basins in northern and western Europe (Price 1999; Ruffell et al. 2002). The aridity peak, however, occurred already in the Late Tithonian (Fig. 2; e.g., Rameil 2005). Superimposed on the general trend were high-frequency climate changes that led to an alternation of more arid and more humid conditions, as for example in the case of sequence-boundary zone Bel where dolomitized microbial mats are overlain by brackish-water, charophyte-bearing limestones (Fig. 5).

A matter of scale

The thickness of the stratigraphic intervals comprising the sequence-boundary zones analyzed is within or very close to the vertical resolution nowadays achieved in seismic profiles (5-15 m; e.g., Praeg 2003). Thus, the Berriasian intervals studied can be seen as outcrop examples of sequenceboundary reflectors mapped in subsurface successions of proximal platform carbonates. Whereas at seismic scale only longer-term trends of relative sea-level change can be interpreted, in the outcrop the imprint of higher frequencies of relative sea-level change is potentially also discernible (Fig. 17). Especially in peritidal successions, high-frequency relative sea-level fluctuations may structure 
the sedimentary record formed during longer-term regressive phases through successive surfaces of subaerial exposure, which can be grouped into a sequence-boundary zone (Figs. 5, 8, 11, 14 and 17). Therefore, a sequence-boundary reflector when expressed in outcrop is not necessarily a single surface but equivalent to a stratigraphic interval, which contains, depending on the sedimentary response to the high-frequency variations of relative sea level, a suite of features indicating loss of accommodation (Fig. 17).

\section{Conclusions}

The Late Jurassic (Kimmeridgian) to Early Cretaceous (Berriasian) platform carbonates of Mount Salève are excellent archives of the major climate and oceanographic changes that occurred during this time interval at the northern margin of the Alpine Tethys. These include: 1) a major transgressive-regressive cycle of relative sea-level change, and 2) a climate shift from a more arid to more humid conditions from the Early to the Late Berriasian.

The major transgressive-regressive cycle is marked by Kimmeridgian transgressive coralbearing limestones, which pass upwards to Tithonian-Berriasian normal-regressive peritidal deposits. The Kimmeridgian limestones are massive, seem to be stacked in an aggrading fashion, and constitute a carbonate system that kept pace with relative sea-level rise. The Tithonian to Berriasian deposits reflect a reduced accommodation and correspond to well-bedded peritidal carbonates. The vertical persistence of upper intertidal to lower supratidal lithofacies throughout the Early Berriasian succession is indicative of an aggradational carbonate system. This is consistent with an early stage of a highstand phase of relative sea level.

The climate change is evidenced by the absence of siliciclastic grains and the presence of sedimentary features such as algal-microbial laminities with desiccation cracks and a calcrete crust 
in the Early Berriasian stratigraphic intervals analyzed, and by the occurrence of abundant detrital quartz and of a coal horizon in the latest Berriasian sedimentary succession. Higher abundance of illite with respect to kaolinite in the Early Berriasian marly intervals, and the higher dominance of kaolinite with respect to illite in the latest Berriasian marl deposits are in accordance with this longterm climatic change.

The four sequence-boundary zones analyzed comprise more than one candidate for a sequence boundary and thus demonstrate that higher-frequency sea-level changes, superposed to the major regressive context, structured this highstand phase. Depending on local sedimentological conditions and on the predominating climate, each sequence-boundary zone developed its own specific features.

The thicknesses of the studied stratigraphic intervals comprising sequence-boundary zones are comparable to the vertical resolution of sequence-boundary reflectors from high-resolution seismic data. Therefore, the detailed stratigraphic logs shown in this study can be regarded as exemplary outcrop analogues of sequence-boundary reflectors mapped in subsurface peritidal carbonate successions.

Acknowledgements We are grateful to Dan Bosence, Marc Aurell, and an anonymous reviewer for their careful reviews and constructive suggestions. Felix Schlagintweit and Carles Martín-Closas are thanked for having determined several fossil specimens. David Jaramillo-Vogel is acknowledged for fruitful discussions on the ideas presented in this paper. We would like to thank Lyndon A. Yose for providing information on the seismic transect from onshore Abu Dhabi shown in this paper. Financial support for this research was provided by the Swiss National Science Foundation grants no. 20121545 and 20-137568.

\section{References}


630 Alsharhan AS, Kendall CGStC (2003) Holocene coastal carbonates and evaporites of the southern 631 Arabian Gulf and their ancient analogues. Earth-Science Reviews 61:191-243

632

633 Aurell M, Bádenas B (2004) Facies and depositional sequence evolution controlled by high634 frequency sea-level changes in a shallow-water carbonate ramp (late Kimmeridgian, NE Spain). 635 Geological Magazine 141:717-733

Bádenas B, Aurell M, Salas R (2004) Three orders of regional sea-level changes control facies and 638 stacking patterns of shallow platform carbonates in the Maestrat Basin (Tithonian-Berriasian, NE Spain). International Journal of Earth Sciences 93:144-162

Bernaus JM, Arnaud-Vanneau A, Caus E (2003) Carbonate platform sequence stratigraphy in a rapidly subsiding area: the Late Barremian-Early Aptian of the Organyà basin, Spanish Pyrenees.

Bernier P (1984) Les formations carbonates du Kimméridgien et du Portlandien dans le Jura méridional. Stratigraphie, micropaleontology et sédimentologie. Doc Lab Géol Lyon 92, 803 pp.

Booler J, Tucker ME (2002) Distribution and geometry of facies and early diagenesis: the key to accommodation space variation and sequence stratigraphy: Upper Cretaceous Congost Carbonate platform, Spanish Pyrenees. Sedimentary Geology 146:225-247

Borgomano JRF (2000) The Upper Cretaceous carbonates of the Gargano-Murge region, southern Italy: a model of platform-to-basin transition. AAPG Bulletin 84:1561-1588 
656 657 658 659 660 661 662 663 664 665 666 667 668 669 670

origin of Cenozoic and Mesozoic "third-order" eustatic sequences. Earth-Science Reviews 109:94112

Bover-Arnal T, Salas R, Moreno-Bedmar JA, Bitzer K (2009) Sequence stratigraphy and architecture of a late early-Middle Aptian carbonate platform succession from the western Maestrat Basin (Iberian Chain, Spain). Sedimentary Geology 219:280-301

Bover-Arnal T, Moreno-Bedmar JA, Salas R, Skelton PW, Bitzer K, Gili E (2010) Sedimentary evolution of an Aptian syn-rift carbonate system (Maestrat Basin, E Spain): effects of accommodation and environmental change. Geologica Acta 8:249-280

Bover-Arnal T, Jaramillo-Vogel D, Showani A, Strasser A (2011) Late Eocene transgressive sedimentation in the western Swiss Alps: Records of autochthonous and quasi-autochthonous biofacies on a karstic rocky shore. Palaeogeography, Palaeoclimatology, Palaeoecology 312:24-39

Carozzi, AV (1955) Sédimentation récifale rythmique dans le Jurassique supérieur du Grand-Salève. Geologische Rundschau 43:433-446

Catuneanu O, Abreu V, Bhattacharya JP, Blum MD, Dalrymple RW, Eriksson PG, Fielding CR, Fisher WL, Galloway WE, Gibling MR, Giles KA, Holbrook JM, Jordan R, Kendall CGStC, Macurda B, Martinsen OJ, Miall AD, Neal JE, Nummedal D, Pomar L, Posamentier HW, Pratt BR, Sarg JF, Shanley KW, Steel RJ, Strasser A, Tucker ME, Winker C (2009) Towards the standardization of sequence stratigraphy. Earth-Science Reviews 92:1-33

Clavel B, Charollais J, Busnardo R, Le Hégarat G (1986) Précisions stratigraphiques sur le Crétacé inférieur basal du Jura méridional. Eclogae geologicae Helvetiae 79: 319-341 
683 Climent-Domènech H, Martín-Closas C, Salas R (2009) Charophyte-rich microfacies in the 684 Barremian of the Eastern Iberian Chain (Spain). Facies 55:387-400

686 Coe AL, Bosence DWJ, Church KD, Flint SS, Howell JA, Wilson RCL (2003). The sedimentary 687 record of sea-level change. Cambridge University Press and the Open University, Cambridge, pp $688 \quad 288$

689

690 Colombié C, Rameil N (2007) Tethyan-to-boreal correlation in the Kimmeridgian using high691 resolution sequence stratigraphy (Vocontian Basin, Swiss Jura, Boulonnais, Dorset). International 692 Journal of Earth Sciences 96:567-591

694 Colombié C, Strasser A (2005) Facies, cycles, and controls on the evolution of a keep-up carbonate 695 platform (Kimmeridgian, Swiss Jura). Sedimentology 52:1207-1227

Curtis CD (1990) Aspects of climatic influence on the clay mineralogy and geochemistry of soils, paleosoils and clastic sedimentary rocks. Journal of the Geological Society of London 147:351-357

Deconinck J-F, Strasser A (1987) Sedimentology, clay mineralogy and depositional environment of

Deville Q (1991) Stratigraphie, sédimentologie et environnements de depots, et analyse séquentielle dans les terrains entre le Kimméridgien supérieur et le Valanginian du Mont-Salève (Haute Savoie, France). $\mathrm{PhD}$ thesis, Université de Genève, pp 141

Deville Q (1990) Chronostratigraphie et lithostratigraphie synthétique du Jurassique supérieur et du 
708 Crétacé inférieur de la partie méridionale du Grand Salève (Haute Savoie, France). Archs Sci Gèneve $709 \quad 31: 215-235$

711 de Saussure H-B (1779-1796) Voyages dans les Alpes précédés d'un essai sur l'histoire naturelle des 712 environs de Genève. Fauche-Borel, Neuchâtel, 4 vols

714 Dunham RJ (1962) Classification of carbonate rocks according to depositional texture. In: Ham WE 715 (ed) Classification of carbonate rocks. AAPG Mem 1:108-121

Dunham RJ (1970) Keystone vugs in carbonate beach deposits. Am Assoc Pet Geol Bull 54: 845

Enay R (1965) Les formations coralliennes de Saint-Germain-de-Joux (Ain). Bull Soc géol France 7:23-

El-Sayed MI (1999) Tidal flat rocks and sediments along the eastern coast of the United Arab Emirates.

Carbonates and Evaporites 14:106-120

Gorin GE, Signer C, Amberger G (1993) Structural configuration of the western Swiss Molasse

Basin as defined by reflection seismic data. Eclogae geol Helv 86:693-716

Gourrat C, Masse J-P, Skelton PW (2003) Hypelasma salevensis (FAVRE, 1913) from the Upper

Kimmeridgian of the French Jura, and the Origin of the Rudist Family Requieniidae. Geologica

732 Gradstein FM, Ogg JG, Smith AG (2004) A Geologic Time Scale 2004. Cambridge University 733 Press, Cambridge, 610 pp 
735 Häfeli C (1966) Die Jura/Kreide-Grenzschichten im Bielerseegebiet (Kt. Bern). Eclogae geol Helv $736 \quad 59: 565-696$

Hardenbol J, Thierry J, Farley MB, Jacquin T, de Graciansky PC, Vail PR (1998) Mesozoic and

Cenozoic sequence chronostratigraphic framework of European basins. In: Graciansky PC,

Hardenbol J, Jacquin T, Vail PR (eds) Mesozoic and Cenozoic Sequence Stratigraphy of European

Basins. SEPM Special Publication 60:3-13, charts 1-8

Hardie LA (1977) Sedimentation on the Modern Carbonate Tidal Flats of Northwest Andros Island,

Bahamas. The Johns Hopkins University Press, Baltimore and London, 224 pp

Hillgärtner H (1998) Discontinuity surfaces on a shallow-marine carbonate platform (Berriasian,

Hillgärtner H (1999) The evolution of the French Jura platform during the Late Berriasian to Early

Valanginian: controlling factors and timing. GeoFocus 1, pp 203

Hillgärtner H, Strasser A (2003) Quantification of high-frequency sea-level fluctuations in shallow-

water carbonates: an example from the Berriasian-Valanginian (French Jura). Palaeogeography,

Palaeoclimatology, Palaeoecology 200:43-63

Hunt D, Tucker ME (1992) Stranded parasequences and the forced regressive wedge systems tract: deposition during base-level fall. Sedimentary Geology 81:1-9 
problem. Sedimentary Geology 175:277-296

762 James NP (1972) Holocene and Pleistocene calcareous crust (caliche) profiles: criteria for subaerial 763 exposure. Journal of Sedimentary Petrology 42:817-836

Joukowsky E, Favre J (1913) Monographie géologique et paléontologique. Mém Soc Phys et Hist nat Genève 37:295-523

Le Hégarat G, Remane J (1968) Tithonique supérieur et Berriasien de l'Ardèche et de l'Hérault: correlation des ammonites et des calpionelles. Géobios 1:7-70

Leeder MR, Harris T, Kirkby MJ (1998) Sediment supply and climate change: implications for basin stratigraphy. Basin Research 10:7-18

Lombard A (1967) Le Salève. In: Guide géologique de la Suisse 2:54-57

Mojon P-O (1988) Contribution à l'étude micropaléontologique, paléoécologique et biostratigraphique des faciès "portlandiens" et "purbeckiens" (limite Jurassique-Crétacé) du Salève

Montañez IP, Osleger DA (1993) Parasequence stacking patterns, third-order accommodation 781 events, and sequence stratigraphy of Middle to Upper Cambrian platform carbonates, Bonanza King 782 Formation, southern Great Basin. In: R.G. Loucks RG, Sarg JF (eds) Carbonate Sequence 783 Stratigraphy. AAPG Mem 57:305-326 
method. Geology 37:779-782

788 Parrish JT, Ziegler AM, Scotese CR (1982) Rainfall patterns and the distribution of coals and 789 evaporites in the Mesozoic and Cenozoic. Palaeogeography, Palaeoclimatology, Palaeoecology $790 \quad 40: 67-102$

Pasquier J-B, Strasser A (1997) Platform-to-basin correlation by high-resolution sequence stratigraphy and cyclostratigraphy (Berriasian, Switzerland and France). Sedimentology 44:10711092

Praeg D (2003) Seismic imaging of mid-Pleistocene tunnel-valleys in the North Sea Basin—high resolution from low frequencies. Journal of Applied Geophysics 53:273-298

Pratt BR, James NP (1986) The St George Group (Lower Ordovician) of western Newfoundland:

800 tidal flat island model for carbonate sedimentation in shallow epeiric seas. Sedimentology 33:313$801 \quad 343$

803 Price GD (1999) The evidence and implications of polar ice during the Mesozoic. Earth-Science 804 Reviews 48:183-210

805

806 Rameil N (2005) Carbonate sedimentology, sequence stratigraphy, and cyclostratigraphy of the 807 Tithonian in the Swiss and French Jura Mountains. A high-resolution record of changes in sea level 808 and climate. GeoFocus 13, pp 246 809

810 Robbin DM, Stipp JJ (1979) Depositional rate of laminated soilstone crust, Florida Keys. Journal of 811 Sedimentary Petrology 49:175-180 
813 Ruffell A, McKinley JM, Worden RH (2002) Comparison of clay mineral stratigraphy to other 814 proxy palaeoclimate indicators in the Mesozoic of NW Europe. Phil Trans R Soc Lond A 360:675$815 \quad 693$

817 Scholle PA, Ulmer-Scholle DS (2003) A color guide to the petrography of carbonate rocks: grains, 818 textures, porosity, diagenesis. AAPG Memoir 77, pp 459

820 Shao L, Zhang P, Ren D, Lei J (1998) Late Permian coal-bearing carbonate successions in southern 821 China: coal accumulation on carbonate platforms. International Journal of Coal Geology 37:235$822 \quad 256$

824 Shinn EA, Lloyd RM, Ginsburg RN (1969) Anatomy of a modern carbonate tidal-flat, Andros 825 Island, Bahamas. Journal of Sedimentary Petrology 39:1202-1228

Signer C, Gorin GE (1995) New geological observations between the Jura and the Alps in the Geneva area, as derived from reflection seismic data. Eclogae geologicae Helvetiae 88:235-265

830 Spence GH, Tucker ME (2007) A proposed integrated multi-signature model for peritidal cycles in 831 carbonates. Journal of Sedimentary Research 77:797-808

833 Steinhauser N, Lombard A (1969) Définition de nouvelles unites lithostratigraphiques dans le 834 Crétacé inférieur du Jura méridional (France). C R Soc Phy Hist Nat Genève 4:100-113

836 Stephenson WJ, Naylor LA (2011) Geological controls on boulder production in a rock coast 837 setting: Insights from South Wales, UK. Marine Geology 283:12-24 
839 Strasser A, Davaud E (1983) Black pebbles of the Purbeckian (Swiss and French Jura): lithology, 840 geochemistry and origin. Eclogae geologicae Helvetiae 76:551-580

842 Strasser A, Hilgen FJ, Heckel FH (2006) Cyclostratigraphy - concepts, definitions, and 843 applications. News1 Stratigr 42:75-114

845 Strasser A, Pittet B, Hillgärtner H, Pasquier J-B (1999) Depositional sequences in shallow 846 carbonate-dominated sedimentary systems: concepts for a high-resolution analysis. Sedimentary 847 Geology 128:201-221

849 Strasser A, Hillgärtner H (1998) High-frequency sea-level fluctuations recorded on a shallow 850 carbonate platform (Berriasian and Lower Valanginian of Mount Salève, French Jura). Eclogae geol 851 Helv 91:375-390

853 Strasser A, Hillgärtner H, Hug W, Pittet, B (2000) Third-order depositional sequences reflecting 854 Milankovitch cyclicity. Terra Nova 12:303-311

856 Strasser A, Hillgärtner H, Pasquier J-B (2004) Cyclostratigraphy timing of sedimentary processes: 857 an example from the Berriasian of the Swiss and French Jura Mountains. In: D’Argenio B, Fischer 858 AG, Premoli Silva I, Weissert H, Ferreri V (eds) Cyclostratigraphy: approaches and case histories. 859 SEPM Spec Publ 81:137-151

861 Strasser A (1988) Shallowing-upward sequences in Purbeckian peritidal carbonates (lowermost 862 Cretaceous, Swiss and French Jura Mountains). Sedimentology 35:369-383

864 Strasser A (1994) Lagoonal-peritidal carbonate cyclicity: French Jura Mountains. In: de Boer PL, 
865 Smith DG (eds) Orbital forcing and cyclic sequences. IAS Spec Publ 19:285-301

866

867 Strasser A, Davaud E, Jedoui Y (1989) Carbonate cements in Holocene beachrock: example from 868 Bahiret el Biban, southeastern Tunisia. Sedimentary Geology 62:89-100

869

870 Strasser A, Davaud E (1986) Formation of Holocene limestone sequences by progradation, 871 cementation and erosion: two examples from the Bahamas. Journal of Sedimentary Petrology $872 \quad 56: 422-428$

873

Van Buchem FSP, Razin P, Homewood PH, Oterdoom WH, Philip J (2002) Stratigraphic organisation of carbonate ramps and organic-rich intrashelf basins: the Natih Formation (Middle Cretaceous) of Northern Oman. AAPG Bulletin 86:21-53

Wright VP (1984) Peritidal carbonate facies models: a review. Geological Journal 19:309-325

Yose LA, Strohmenger CJ, Al-Hosani I, Bloch G, Al-Mehairi Y (2010) Sequence-stratigraphic 881 evolution of an Aptian carbonate platform (Shu'aiba Formation), eastern Arabian Plate, onshore Abu 882 Dhabi, United Arab Emirates. In: van Buchem FSP, Al-Husseini MI, Maurer F, Droste HJ (eds) 883 Barremian - Aptian stratigraphy and hydrocarbon habitat of the eastern Arabian Plate. GeoArabia 884 Spec Publ 4:309-340

Figures

Fig. 1 Location map of the studied section in the northwestern cliffs of Mount Salève in E France.

Fig. 2 Chronostratigraphic framework for the Kimmeridgian, Tithonian and Berriasian of Mount 
891 Salève (E France). The sequence boundaries targeted in this study are underlined in red. Note that 892 besides a small phase-lag, the major Kimmeridgian-Berriasian transgressive-regressive cycle 893 interpreted in Mount Salève fits rather well with the one reported for the European basins 894 (Hardenbol et al. 1998). Note also that the palaeoclimatic conditions recognized in Mount Salève 895 are in accordance with the Kimmeridgian-Berriasian northwestern European climatic trends 896 reported in the literature (Ruffell et al. 2002). The Late Jurassic palaeoclimatic data of Mount 897 Salève is taken from Rameil (2005). Modified from Strasser and Hillgärtner (1998). Formation 898 boundaries are marked in dashed lines because their exact biostratigraphic position is not known. $899 \mathrm{MFZ}=$ maximum flooding zone, $\mathrm{T}=$ Transgressive, $\mathrm{R}=$ Regressive.

901 Fig. 3 Large-scale sequence-stratigraphic interpretation of Mount Salève. a Panoramic 902 photomosaic, looking from NW. b Sequence-stratigraphic interpretation. Red lines are faults; the 903 gray area corresponds to the northwestern, vertical flank of an anticline. HNR: highstand normal904 regressive deposits; T: transgressive deposits; MFZ: maximum-flooding zone. Arrow shows 905 position of studied section.

907 Fig. 4 Field photographs of the Kimmerdigian-Berriasian sedimentary succesion of Mount Salève. 908 a Large-scale sequence stratigraphic framework of Mount Salève. Note how massive, thick, non909 bedded carbonates (Kimmerdigian, below) interpreted as transgressive deposits are separated by a 910 maximum-flooding zone from well-bedded limestones (Tithonian-Berriasian, above), which are 911 regarded as a highstand normal-regressive genetic type of deposit. HNR: highstand normal912 regressive deposits; T: transgressive deposits; MFZ: maximum-flooding zone. Arrow shows 913 position of studied section. Houses at the bottom-left corner for scale. b Outcrop view of the well914 bedded highstand normal-regressive Berriasian strata of Mount Salève. The position of the 915 sequence boundary (SB) Be2 of Strasser and Hillgärtner (1998) that separates the Early Berriasian 916 Tidalites-de-Vouglans Formation from the late Early-Middle Berriasian Goldberg Formation is 
917 outlined in red. Note how the beds of the Tidalites-de-Vouglans Formation become thinner close to

918 the sequence boundary, reflecting a loss of accommodation.

920 Fig. 5 Measured $\log$ and interpretation of the stratigraphic interval below and above sequence 921 boundary (SB) Be 1. Cyclostratigraphic interpretation according to Strasser and Hillgärtner (1998).

923 Fig. 6 Sequence boundary Be1. a Outcrop photograph of the strata surrounding SB Be1. b 924 Interpretation of Fig. 6a. Note the unconformable nature of SB Be1 and how the overlying strata 925 display irregular bounding surfaces, suggesting erosion and channeling. Some beds pinch out 926 laterally. A1 to F1 labels correspond to beds referred to in the text and indicated in Fig. 5; hammer = $927 \quad 32 \mathrm{~cm}$.

929 Fig. 7 Sedimentary facies around SB Be1. a Photomicrograph of moderately-sorted grainstone 930 microfacies characteristic of the Chailley Formation, bed A1. b Photomicrograph of mudstone 931 microfacies of algal-microbial mats exhibiting a storm-lag deposit constituted by moulds of sand932 sized skeletal fragments found in the lower part of the Tidalites-de-Vouglans Formation, bed E1. c 933 Close-up view of black granules and pebbles, bed $\mathrm{C} 1$; visible part of pen $=6.4 \mathrm{~cm}$. d Detail of 934 ripple structures preserved in algal-microbial mat deposits, bed C1. e Photomicrograph of a conifer 935 fragment present in low-energy subtidal deposits, bed D1. f Photomicrograph of wackestone 936 microfacies of brackish-water carbonates containing porocharacean stems and gyrogonites, bed F1.

938 Fig. 8 Measured log and interpretation of the stratigraphic interval analyzed surrounding sequence 939 boundary Be 2. See Fig. 5 for legend. Cyclostratigraphic interpretation according to Strasser and 940 Hillgärtner (1998).

942 Fig. 9 Outcrop photograph of the strata surrounding SB Be2. Note how the beds are laterally 
continuous. D2 to N2 labels correspond to beds referred to in the text and indicated in Fig. 8.

945 Fig. 10 Sedimentary facies around SB Be2. a Close-up view of polygonal desiccation cracks 946 present at the top of the Tidalites-de-Vouglans Formation, bed E2. b Photomicrograph of very well947 sorted grainstone of micritized ooids in the lowermost part of the Goldberg Formation, bed G2. c 948 Irregularly oriented keystone vugs in the upper part of bed G2. d Close-up view of a fracture filled 949 with a breccia/conglomerate deposit within the partially broken grainstone of bed G2. e Detail of 950 the calcrete laminar crust (H2) overlying bed G2. Note the presence of a marly interval followed by 951 a poorly sorted breccia/conglomerate (I2) above the calcrete crust. f Close-up view of complex 952 cross-bedding structures exhibited by the grainstone of bed L2. Note the irregular, erosive surface 953 of the bed and the overlying breccia/conglomerate deposit (M2); visible part of pen $=2.9 \mathrm{~cm}$.

955 Fig. 11 Measured log and interpretation of the stratigraphic interval surrounding sequence boundary 956 Be 4. See Fig. 5 for legend. Cyclostratigraphic interpretation according to Strasser and Hillgärtner 957 (1998).

Fig. 12 Outcrop photograph of the strata surrounding sequence boundary Be4. Note the presence of 960 a laterally continuous decimetre-thick breccia. C4 to G4 labels correspond to beds referred to in the 961 text and indicated in Fig. 11.

Fig. 13 Sedimentary facies around SB Be4. a Photomicrograph of characteristic fenestral porosity 964 exhibited by the mudstones displaying desiccation polygons in the uppermost Goldberg Formation, 965 bed D4. b Detail of the breccia/conglomarate deposit (E4). F4 and G4 correspond to a brackish966 water wackestone and a fully-marine grainstone deposit, respectively; hammer $=32 \mathrm{~cm}$. c 967 Microfacies of porocharacean remains showing sections of gyrogonites and thalli, bed F4. d 968 Photomicrograph of moderately-sorted peloidal-skeletal grainstone texture typical of the base of the 
971 Fig. 14 Measured log and interpretation of the stratigraphic interval surrounding sequence boundary 972 Be 8. See Fig. 5 for legend. Cyclostratigraphic interpretation according to Strasser and Hillgärtner (1998).

Fig. 15 Outcrop photograph of the strata surrounding SB Be8. This boundary also marks the limit between the Vions and Chambotte formations. Note how the beds are laterally continuous. H8 to R8 labels correspond to beds referred to in the text and indicated in Fig. 14. White panel is a station of a didactic geological trail; hammer $=32 \mathrm{~cm}$.

Fig. 16 Sedimentary facies around SB Be8. a Photomicrograph of moderately-sorted peloidal981 skeletal grainstone in the upper part of the Vions Formation, bed A8. b Photomicrograph of 982 siliciclastic-influenced lithofacies characteristic of the uppermost part of the Vions Formation, bed L8. Note abundant angular to subrounded quartz grains. c Close-up view of the coal horizon (N8). M8 and O8 correspond to burrowed limestones with a packstone texture that belong respectively to the top of the Vions and to the base of the Chambotte formations (see Figs. 14 and 15). The reddish colour displayed by bed M8 is the result of iron impregnation; visible part of pen $=4.2 \mathrm{~cm}$. $\mathbf{d}$ Detail of Thalassinoides burrows preserved in bed O8; visible part of hammer $=11 \mathrm{~cm}$.

Fig. 17 Conceptual figure comparing a sequence-boundary reflector mapped on seismic data with an outcropping sequence-boundary zone. Note that a sequence-boundary reflector when seen in outcrop may present several subaerial exposure surfaces and, thus, several candidate surfaces for a sequence boundary. The sequence-boundary zone was structured by high-frequency sea-level fluctuations, whereas the sequence-boundary reflector only records a relative sea-level fall of the longer-term trend. The seismic cross section is taken from Yose et al. (2010) and shows highstand 
995 aggrading platform carbonates of the Shu'aiba Formation (Aptian) from onshore Abu Dhabi (UAE). 996 Reflector 1 marks the top of the Shu'aiba Formation, which corresponds to a regional sequence 997 boundary related to subaerial exposure. This surface also corresponds to the top of the Shu'aiba 998 reservoir, which is sealed by the shales of the Nahr Umr Formation (Albian). Reflector 2 marks the 999 base of the Shu'aiba reservoir. The field view corresponds to the Late Jurassic-Early Cretaceous 1000 succession of Mount Salève shown in Fig. 4a. SBZ: sequence-boundary zone; HNR: highstand 1001 normal-regressive deposits; T: transgressive deposits; MFZ: maximum-flooding zone. 


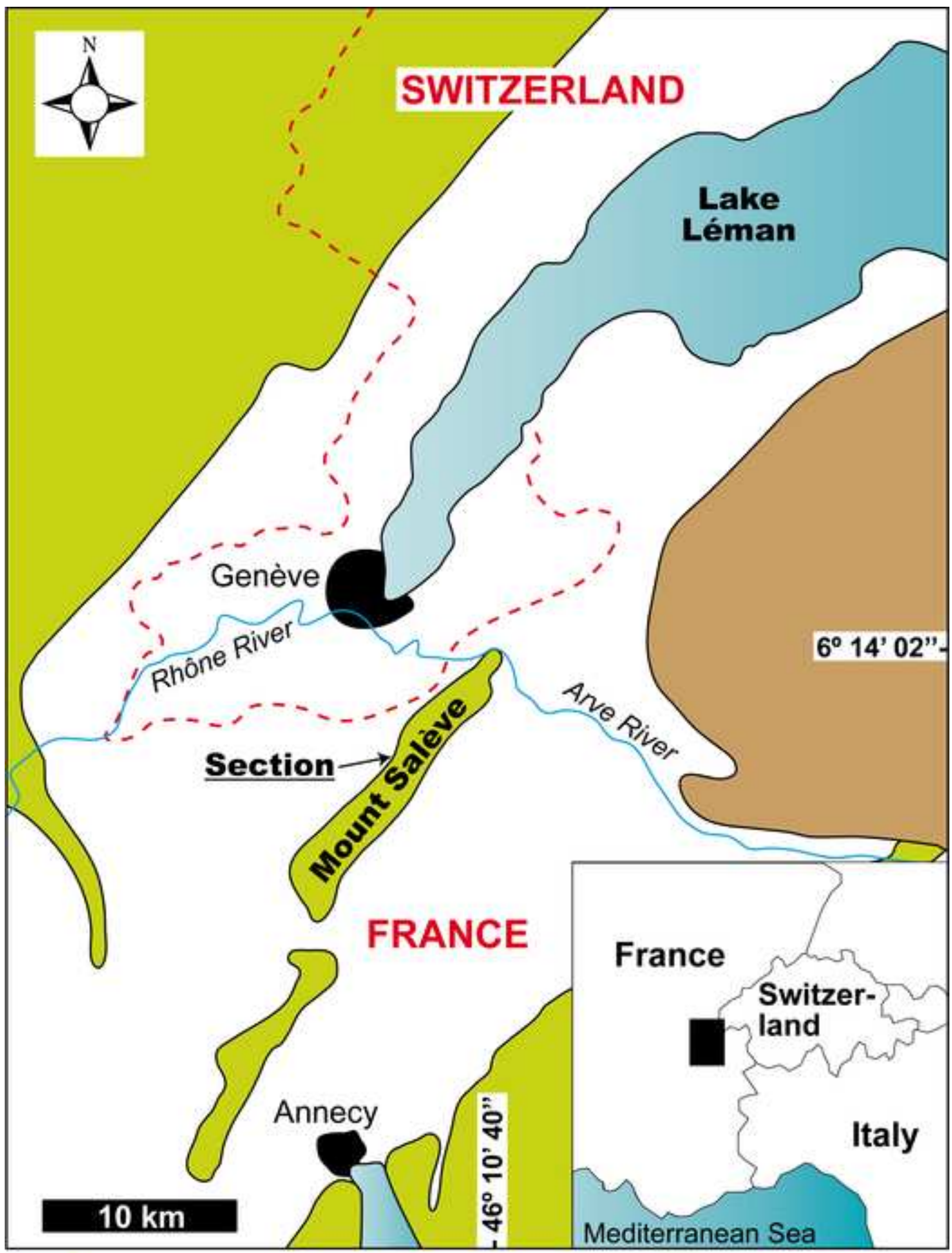




\section{Figure 2}

Click here to download high resolution image

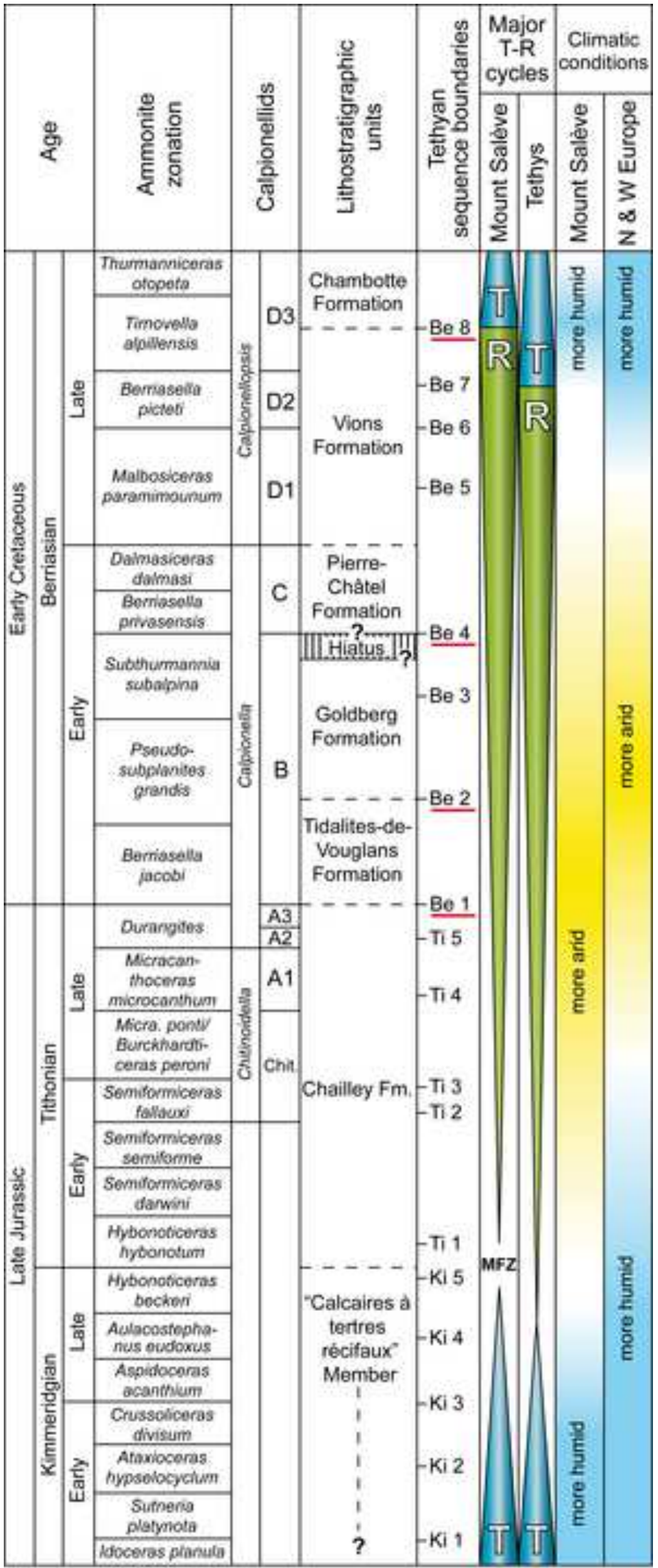


Figure 3

Click here to download high resolution image

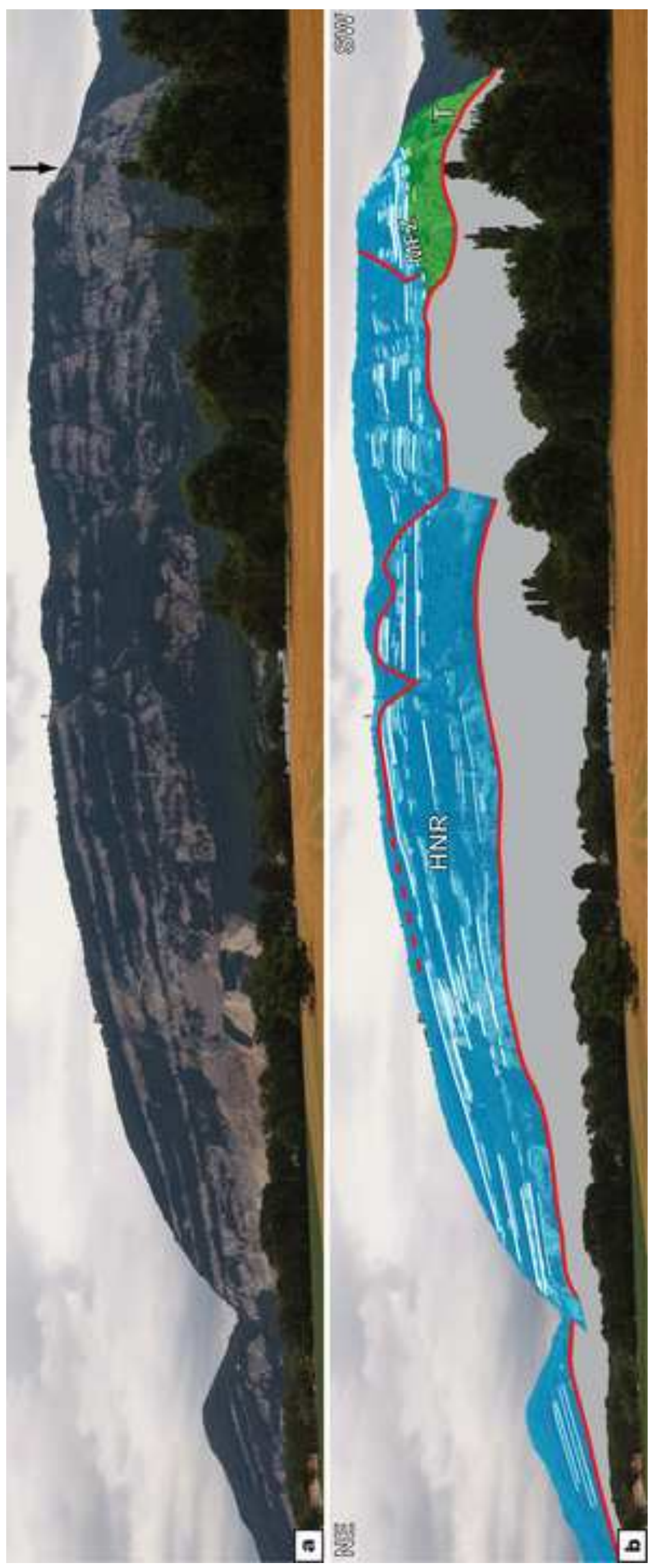



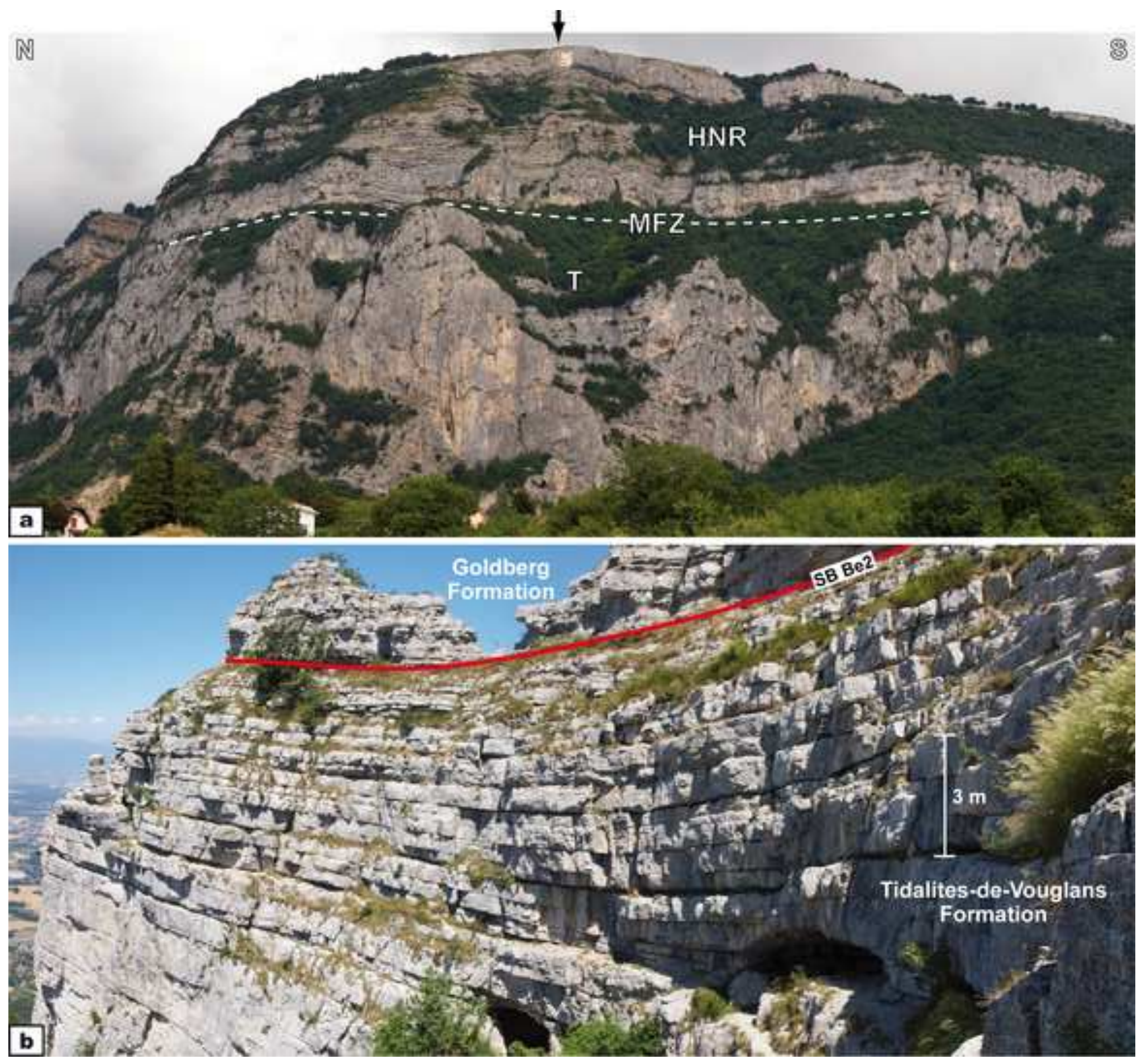


\begin{tabular}{|c|c|c|}
\hline & Coal & m Marl \\
\hline & Marl & M Mudstone \\
\hline & & W Wackestone \\
\hline y. & Sandy limestone & P Packstone \\
\hline$\frac{1}{11}$ & Limestone & G Grainstone \\
\hline$\Delta \Delta$ & Breccia/congl. & B Breccia/congl. \\
\hline$\Delta$ & \multicolumn{2}{|l|}{ Desiccation cracks } \\
\hline 2 & \multicolumn{2}{|l|}{ Root bioturbation } \\
\hline$\alpha$ & \multicolumn{2}{|l|}{ Bioturbation } \\
\hline \# & \multicolumn{2}{|l|}{ Coral fragments } \\
\hline V & \multicolumn{2}{|l|}{ Bryozan fragments } \\
\hline 0 & \multicolumn{2}{|l|}{ Serpulids } \\
\hline 4 & \multicolumn{2}{|l|}{ Plant remains } \\
\hline - & \multicolumn{2}{|l|}{ Keystone vugs } \\
\hline$\tau$ & \multicolumn{2}{|l|}{ Birdseyes } \\
\hline$\star$ & \multicolumn{2}{|c|}{ Echinoderm fragments } \\
\hline$x$ & \multicolumn{2}{|c|}{ Bioclasts (undifferentiated) } \\
\hline$\sim$ & \multicolumn{2}{|c|}{ Other bivalve fragments } \\
\hline$\mu$ & \multicolumn{2}{|l|}{ Oyster fragments } \\
\hline$\theta$ & \multicolumn{2}{|l|}{ Ostracodes } \\
\hline - & \multicolumn{2}{|l|}{ Peloids } \\
\hline 9 & \multicolumn{2}{|c|}{ Gastropod fragments } \\
\hline 8 & \multicolumn{2}{|l|}{ Other foraminifera } \\
\hline (1) & \multicolumn{2}{|l|}{ Miliolids } \\
\hline$\theta$ & \multicolumn{2}{|l|}{ Charophytes } \\
\hline$\not$ & \multicolumn{2}{|c|}{ Green algae fragments } \\
\hline$\infty$ & \multicolumn{2}{|l|}{ Oncoids } \\
\hline ค & \multicolumn{2}{|l|}{ Ooids } \\
\hline$\Delta$ & \multicolumn{2}{|l|}{ Lithoclasts } \\
\hline 4 & \multicolumn{2}{|c|}{ Black granules and pebbles } \\
\hline$\sim$ & \multicolumn{2}{|c|}{ Algal-microbial mats } \\
\hline$\rightarrow$ & \multicolumn{2}{|l|}{ Cross-bedding } \\
\hline
\end{tabular}

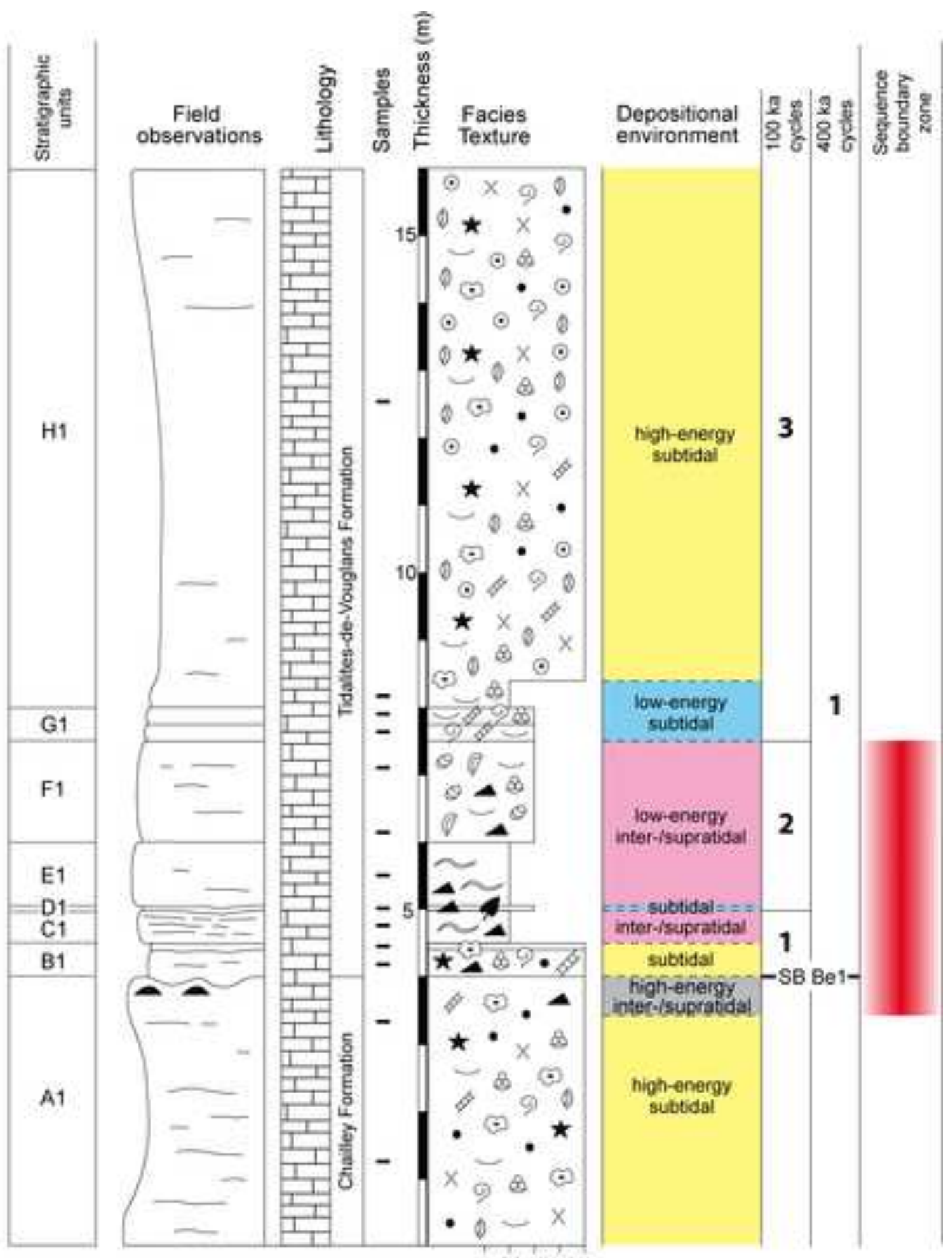

m. MWP 


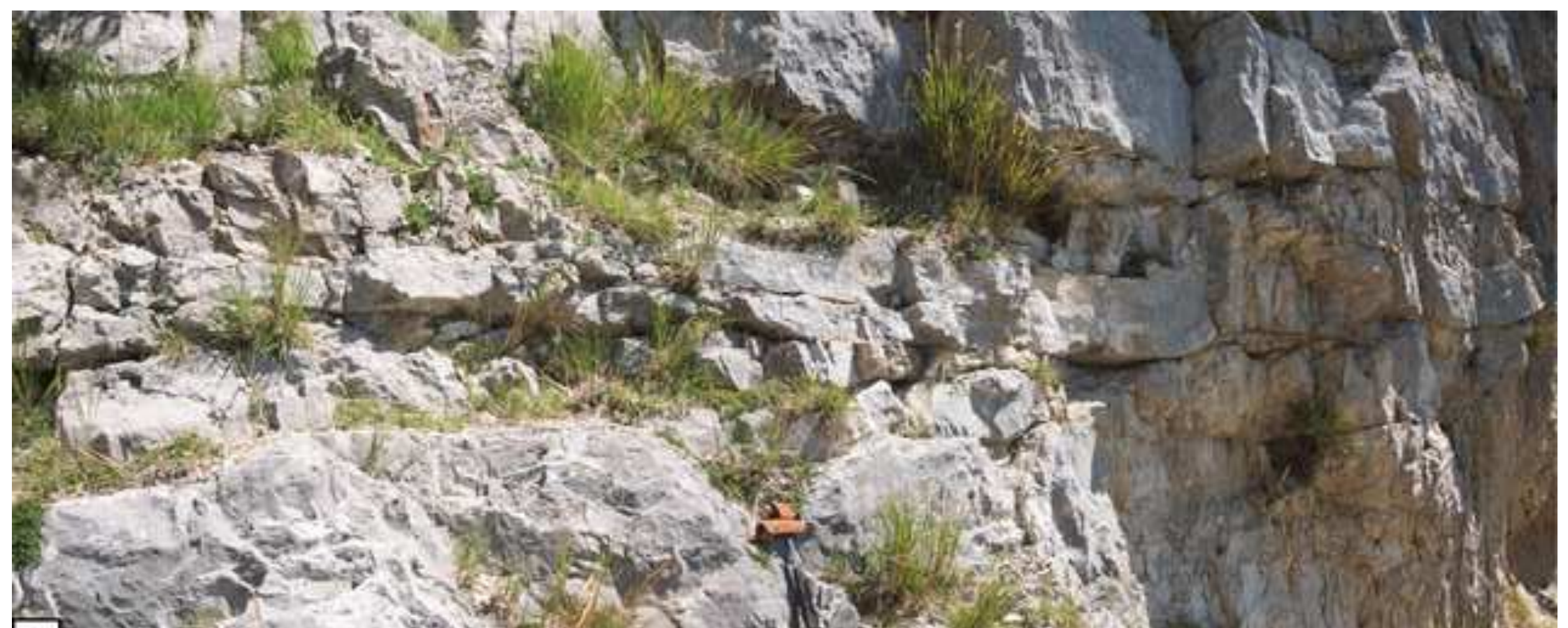

a 5 s.
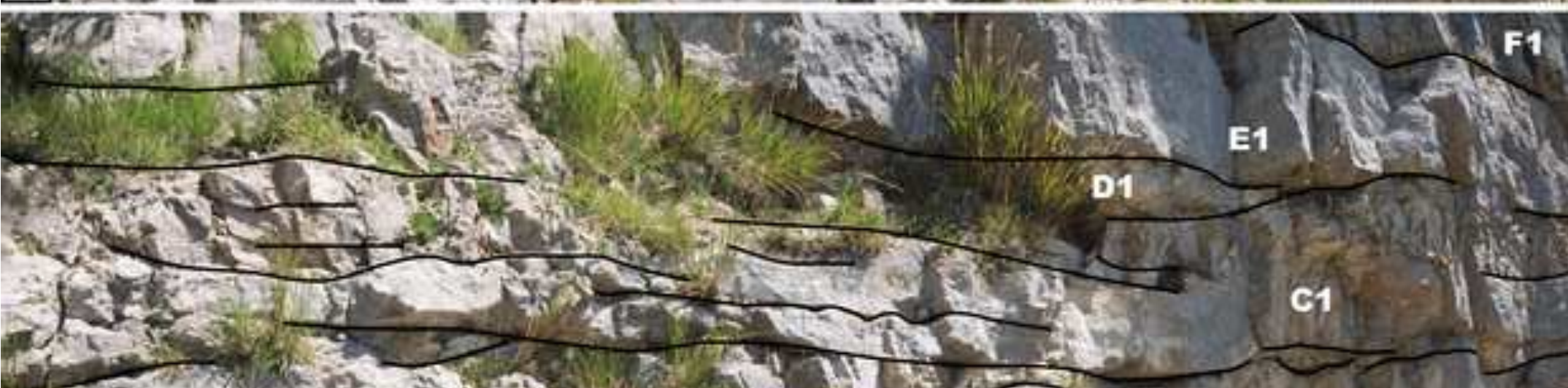

Tialaites-de-Vouglans

Formation

Q4) 1 (n)

Chailley Formation



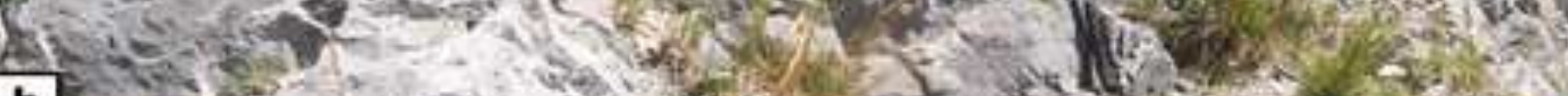

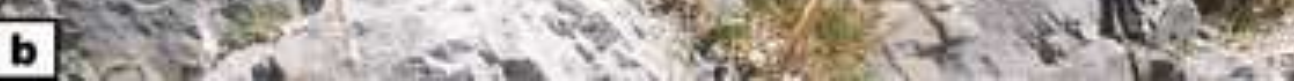

C1

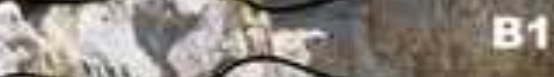

B1

A1 $\quad$, 







Click here to download high resolution image

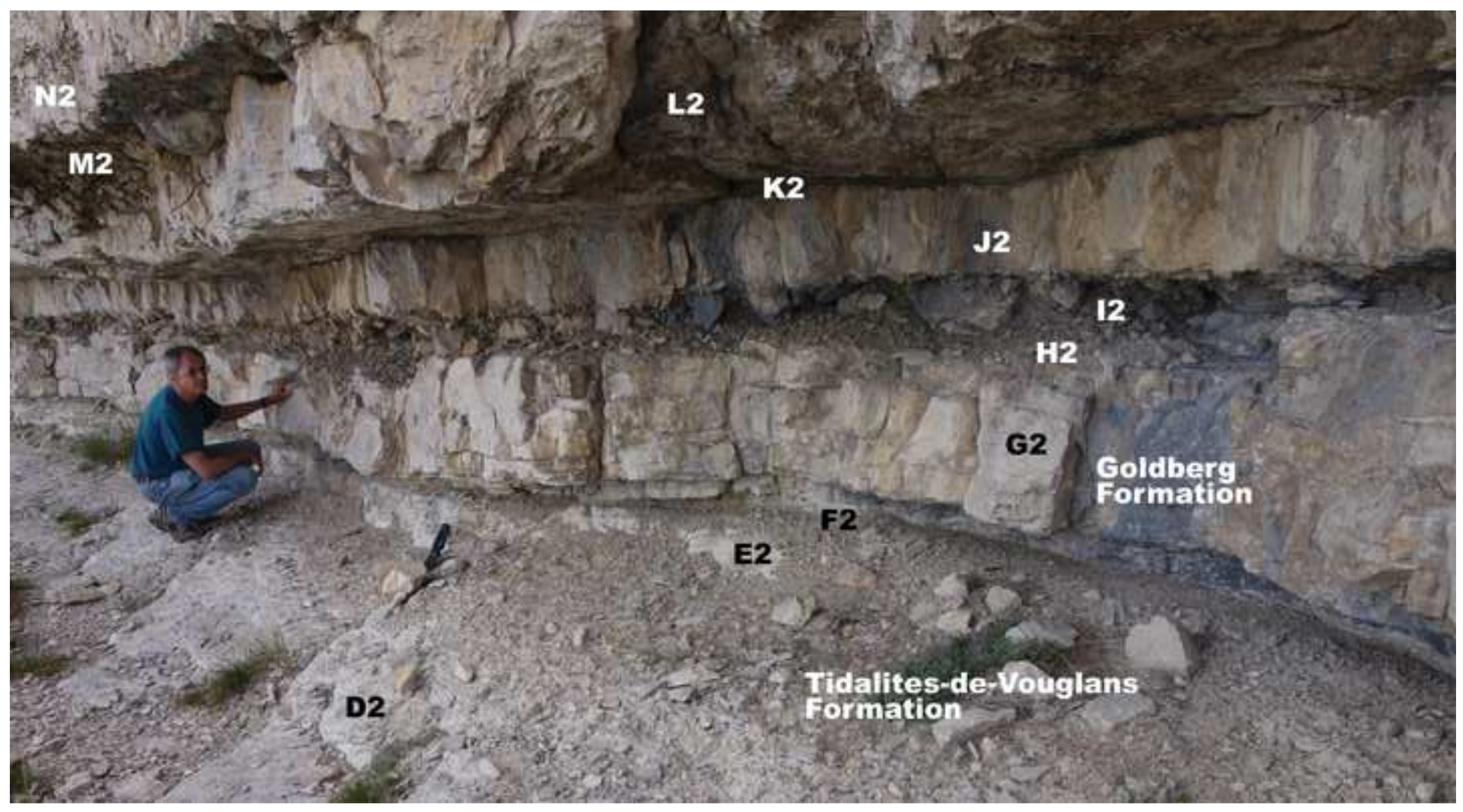



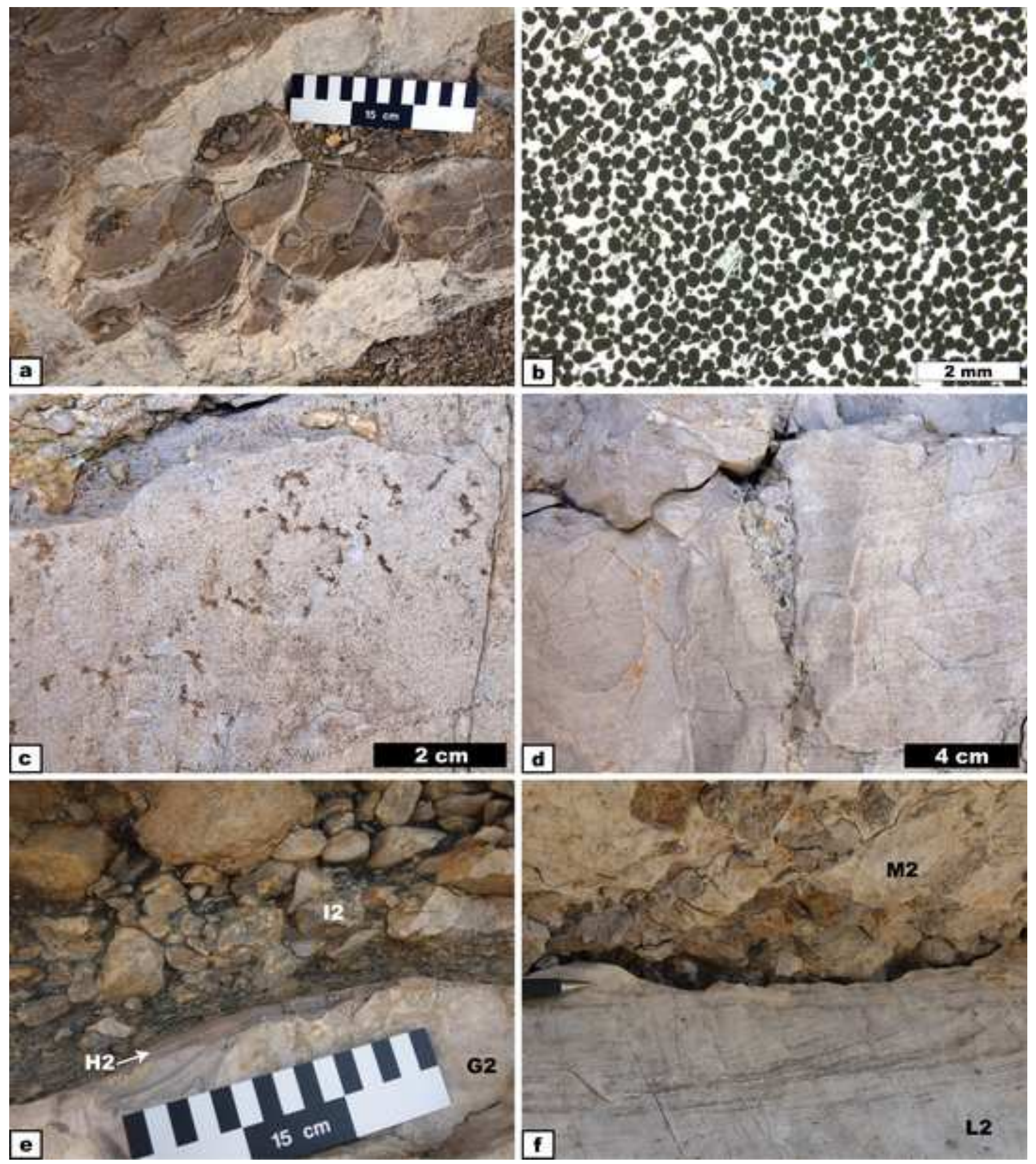












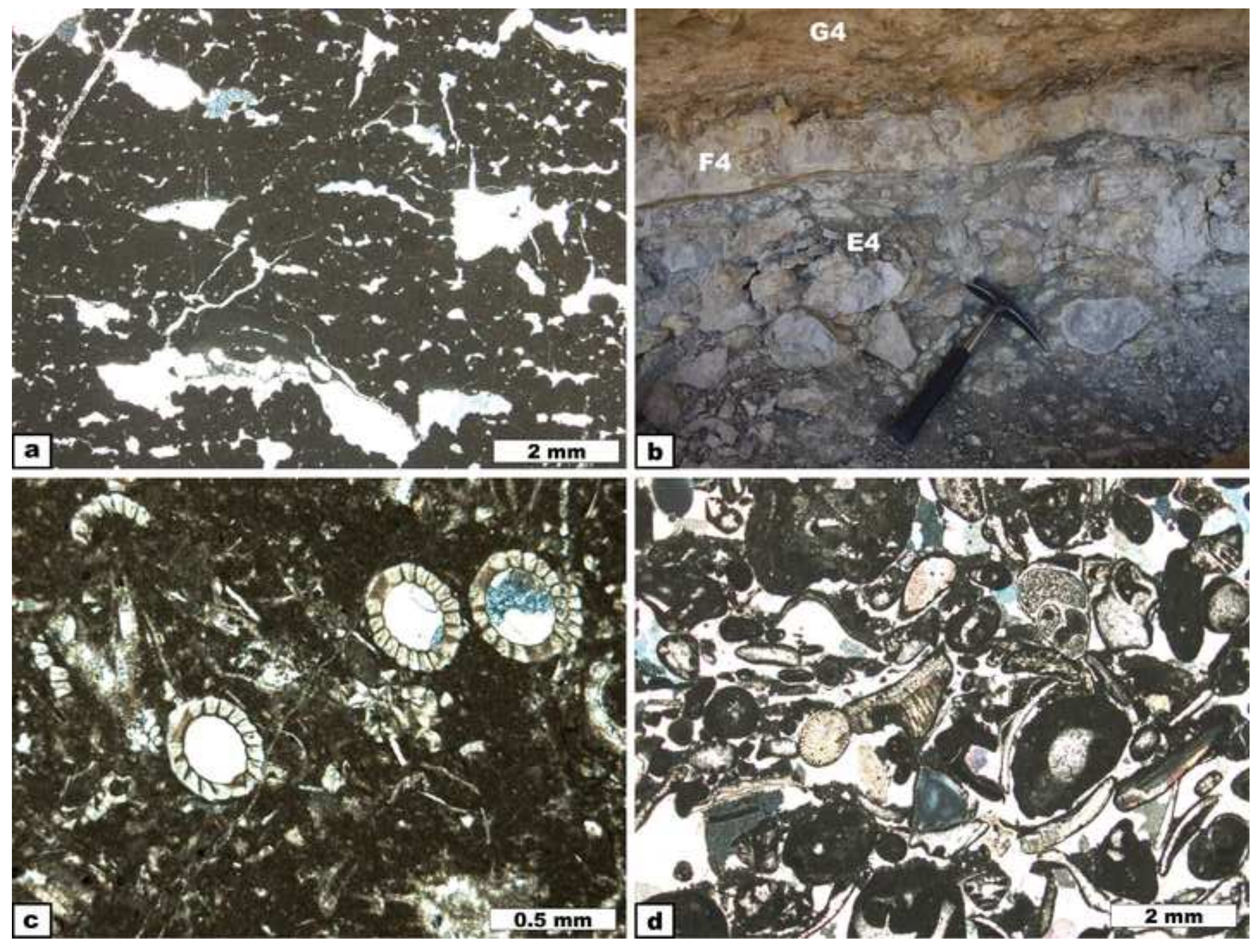


Figure 14

Click here to download high resolution image




Click here to download high resolution image

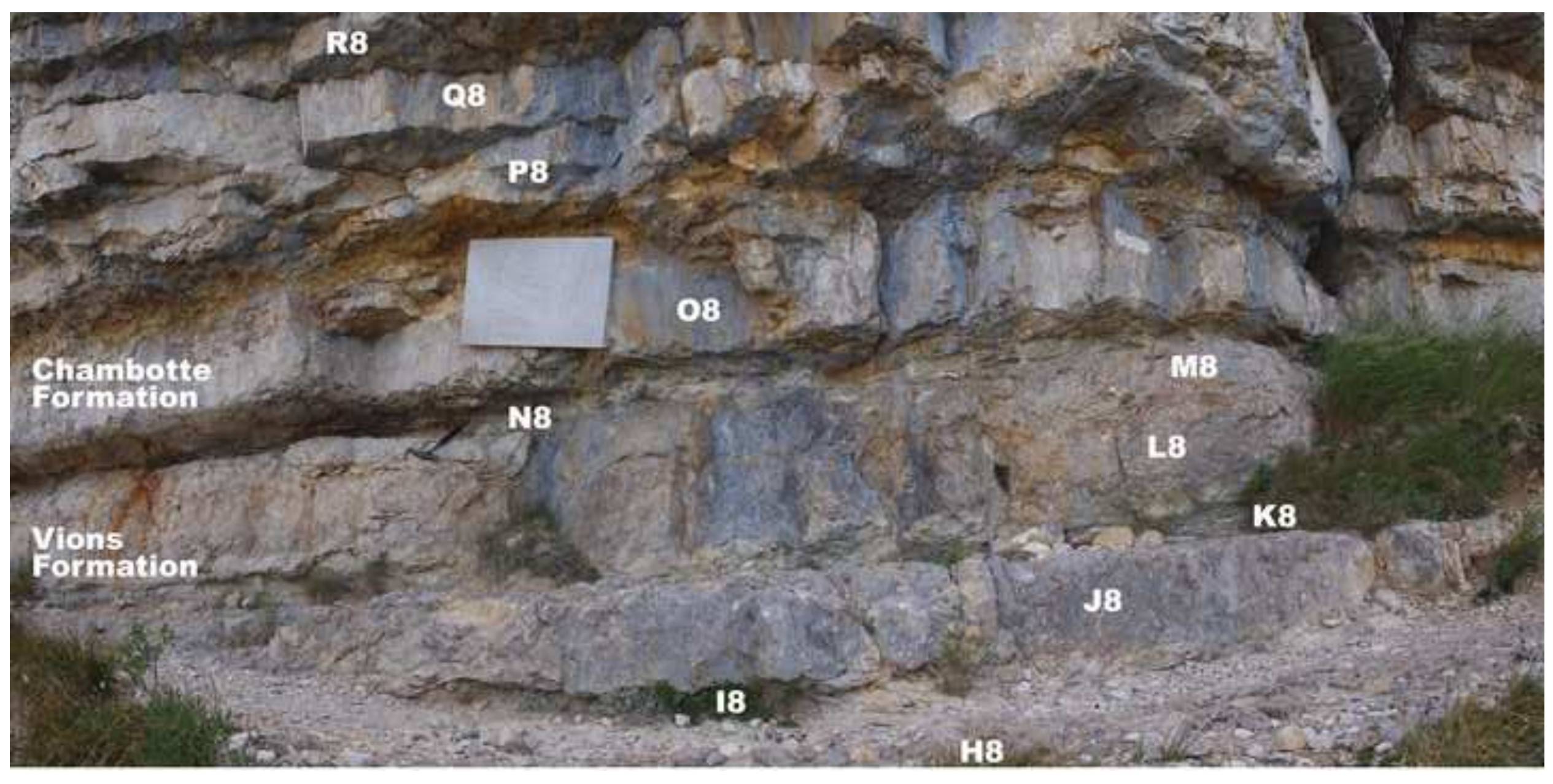

\section{K8}

Click here to download high resolution image

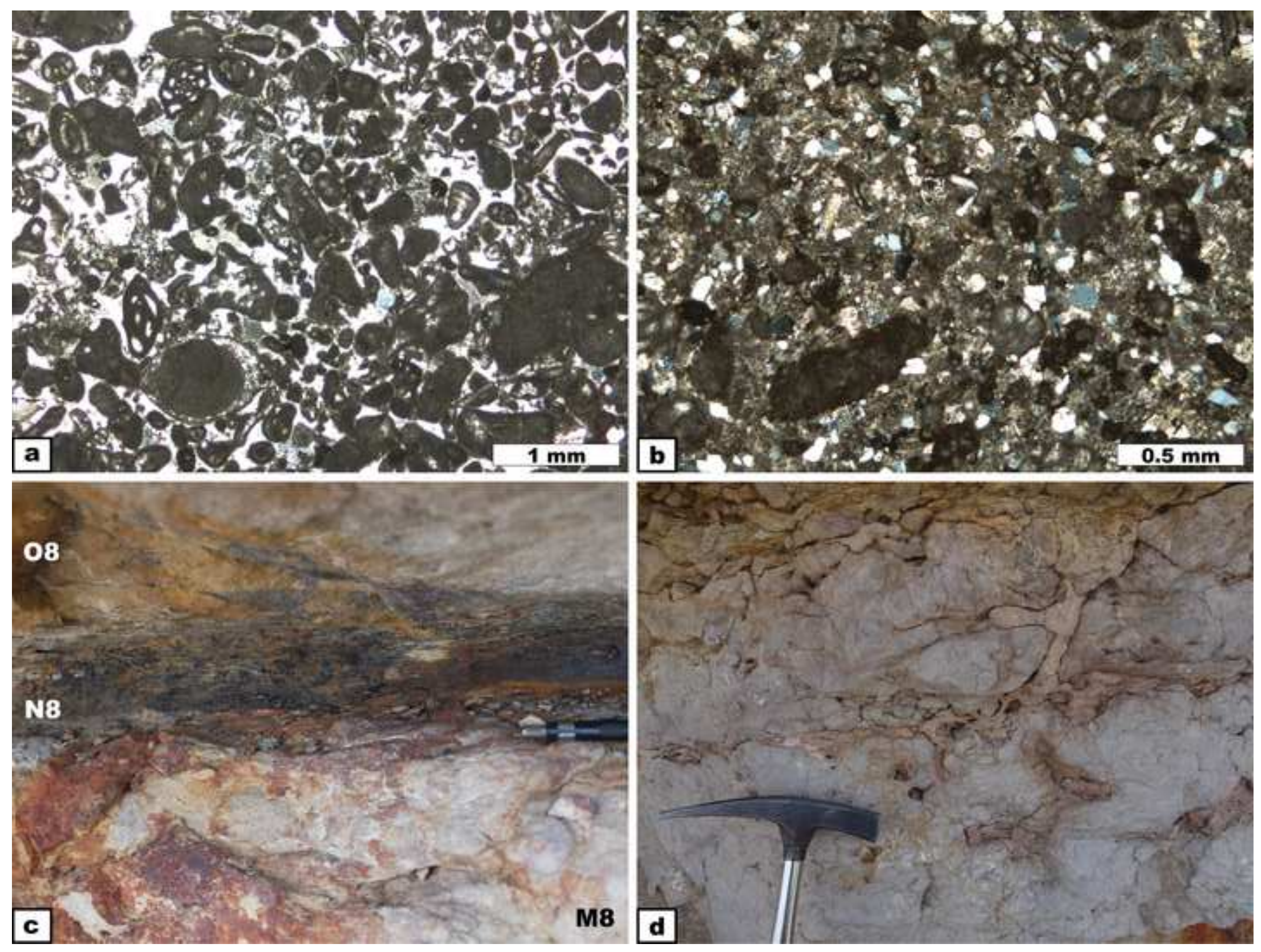




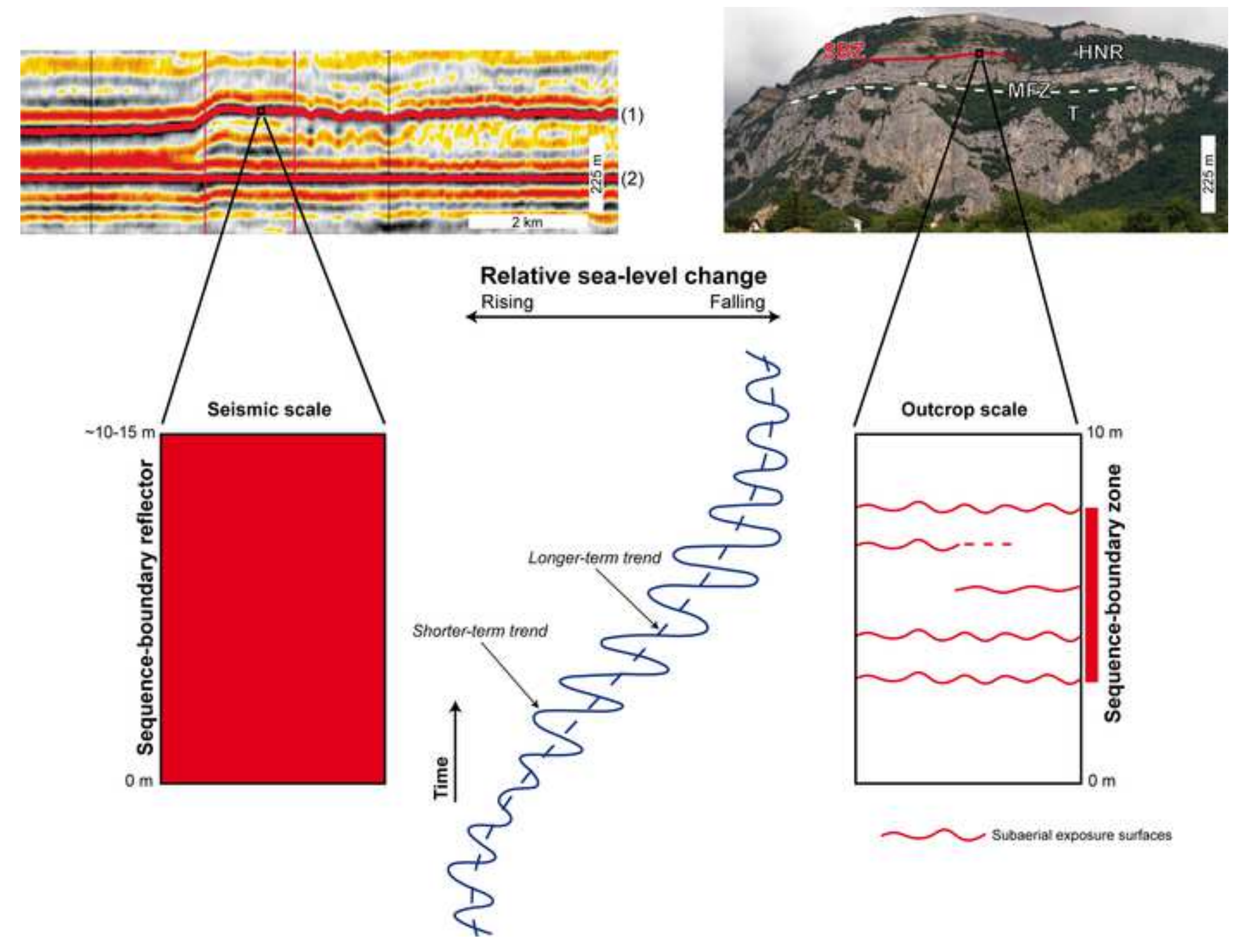

